\title{
Revision of Two Prioniodontid Species (Conodonta) from the Early Ordovician Honghuayuan Formation of Guizhou, South China
}

\author{
Yong Yi Zhen ${ }^{1 *}$, JiAnbo LiU ${ }^{2}$, AND IAN G. PERCIVAL ${ }^{3}$ \\ ${ }^{1}$ Australian Museum, 6 College Street, Sydney NSW 2010, Australia \\ yongyi@austmus.gov.au \\ ${ }^{2}$ Department of Geology, \\ Peking University, Beijing 100871, P.R. China \\ jbliu@pku.edu.cn \\ ${ }^{3}$ Geological Survey of New South Wales, Department of Primary Industries, \\ State Geoscience Centre, 947-953 Londonderry Road, Londonderry NSW 2753, Australia
}

ian.percival@minerals.nsw.gov.au

\begin{abstract}
The septimembrate conodonts Acodus triangularis (Ding in Wang, 1993) and Prioniodus honghuayuanensis n.sp., are described and illustrated from Guizhou, South China where both species are widely distributed in Lower Ordovician strata. The adenticulate $A$. triangularis, which ranges through the middle and upper parts of the Honghuayuan Formation, is morphologically more primitive than the denticulate $P$. honghuayuanensis, which is present from the uppermost Honghuayuan Formation into the lower part of the succeeding Dawan Formation. Prioniodus honghuayuanensis, elements of which were previously ascribed to Oepikodus communis (Ethington \& Clark, 1964), appears to be closely related to a species of Prioniodus from the basal Whiterockian of Utah, North America.
\end{abstract}

Zhen, Yong Yi, Jianbo LiU \& IAn G. Percival, 2005. Revision of two prioniodontid species (Conodonta) from the Early Ordovician Honghuayuan Formation of Guizhou, South China. Records of the Australian Museum 57(2): 303-320.

Conodonts from the Honghuayuan Formation of Guizhou Province, South China were first studied by An (1987) in the Honghuayuan and Ganxi sections (Fig. 1). In the Honghuayuan section, An (1987) recognized three conodont assemblages with the lowermost consisting only of coniform species. The middle assemblage is characterized by the occurrence of Serratognathus diversus An, 1981. The upper assemblage is much higher in diversity, with the appearance of a number of pectiniform species of Prioniodus, Bergstroemognathus and Rhipidognathus. Similar faunas were also recorded from the Honghuayuan Formation of

* author for correspondence
Yanhe, northern Guizhou (An, 1987; X.Y. Chen et al., 1995), and are widely distributed in the Honghuayuan Formation and age equivalent units in South China (An et al., 1985; An, 1987; Wang, 1993).

More recently, conodont samples were collected from Lower Ordovician sections in Guizhou and other parts of South China with the aim of revising the faunas to provide support for a more precise biostratigraphic correlation and age alignment, both regionally and internationally. This revision will assist our understanding of the origin, radiation and phylogeny of the prioniodontid and related clades 


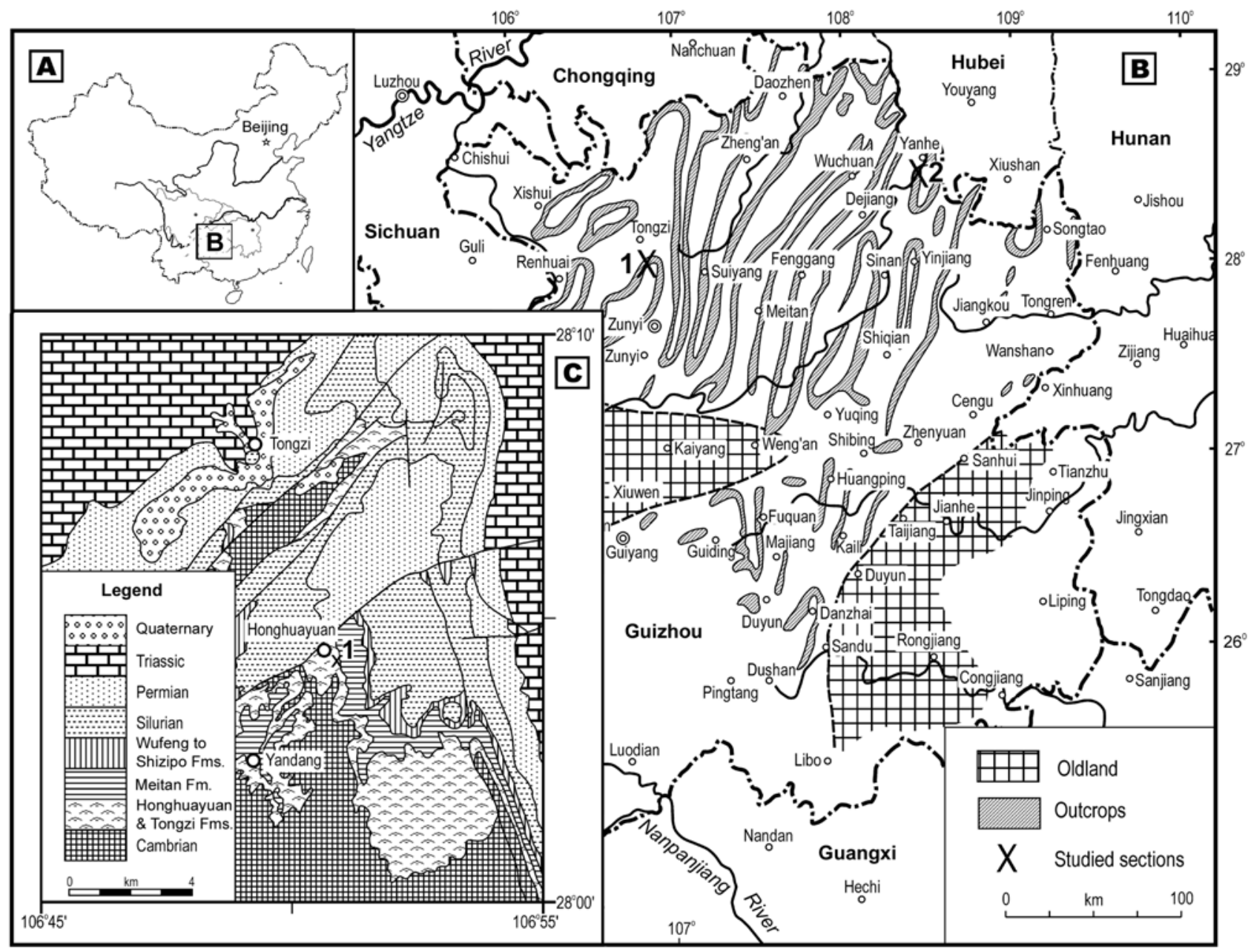

Fig. 1. Locality maps of the study areas. (A) China showing the location of Guizhou Province. $(B)$ northeast Guizhou showing the distribution of the Ordovician rocks (after Gao, 1976) and the locations of two sampled sections for this study: 1) Honghuayuan Section of Tongzi; 2) Ganxi Section of Yanhe. $(C)$ simplified geological map of the area in the vicinity of Honghuayuan village, showing the location of the Honghuayuan Section (Geology information modified from 1:200 000 Geology Map of Tongzi by Guizhou Regional Geological Survey, 1978).

through the late Early Ordovician. The present contribution is the first of several publications arising from this ongoing research project.

\section{Regional geological setting and lithostratigraphy}

The Honghuayuan Formation was initially named the Honghuayuan Limestone by Chang \& Sheng (1958) based on $40 \mathrm{~m}$ of grey, thick-bedded limestone at Honghuayuan, $7 \mathrm{~km}$ south of Tongzi County town, Guizhou (Fig. 1B,C). Zhang et al. (1964) renamed the unit the Honghuayuan Formation, which has been widely used to describe upper Lower Ordovician strata in South China (Wang et al., 1996). The formation conformably overlies the Tongzi Formation. The contact with the overlying Meitan Formation is conformable and gradational (Fig. 1C).

The Honghuayuan Formation in the type section is a medium- to thick-bedded skeletal grainstone and packstone with thin-bedded to nodular skeletal wackestone (Fig. 2). Lime mudstone and shales are rare. Skeletal debris is mostly composed of cephalopods, brachiopods, trilobites, Archaeoscyphia, and bryozoans. The high biotic diversity suggests deposition in a well-circulated neritic environment.
Abundant skeletal grainstones and cross bedding indicate that the formation was mostly deposited in a shoreward environment in the high-energy, shallow subtidal zone (Fig. 2), although lower-energy, deep subtidal sediments, e.g., nodular argillaceous lime mudstone, are also present. Deposition of carbonates of the Honghuayuan Formation ceased due to sea level rise, to be replaced by an increasing supply of terrigenous muds, and then greyish green mudstone (the Meitan Formation) was deposited in Guizhou (Fig. 1C).

The Honghuayuan Formation is widely distributed in Guizhou (Fig. 1B) as well as on the Yangtze Platform with similar lithofacies in the Honghuayuan section (Wang et $a l .$, 1996). Near shore facies of the formation deposited adjacent to eroded land (or island) areas are more dolomitic than the type section. Some patch reefs, which are mainly formed by abundant Calathium and less common Archaeoscyphia (Zhu et al., 1995) were reported from the Huanghuachang section in Yichang, Hubei. The thickness of the Honghuayuan Formation on the Yangtze Platform is commonly 20 to $50 \mathrm{~m}$, varying from a few metres to more than one hundred metres. In Guizhou, the thickness increases to more than $130 \mathrm{~m}$ northeastwards from the "Qianzhong Oldland" (an erosional land area at the time) (Fig. 1B). 


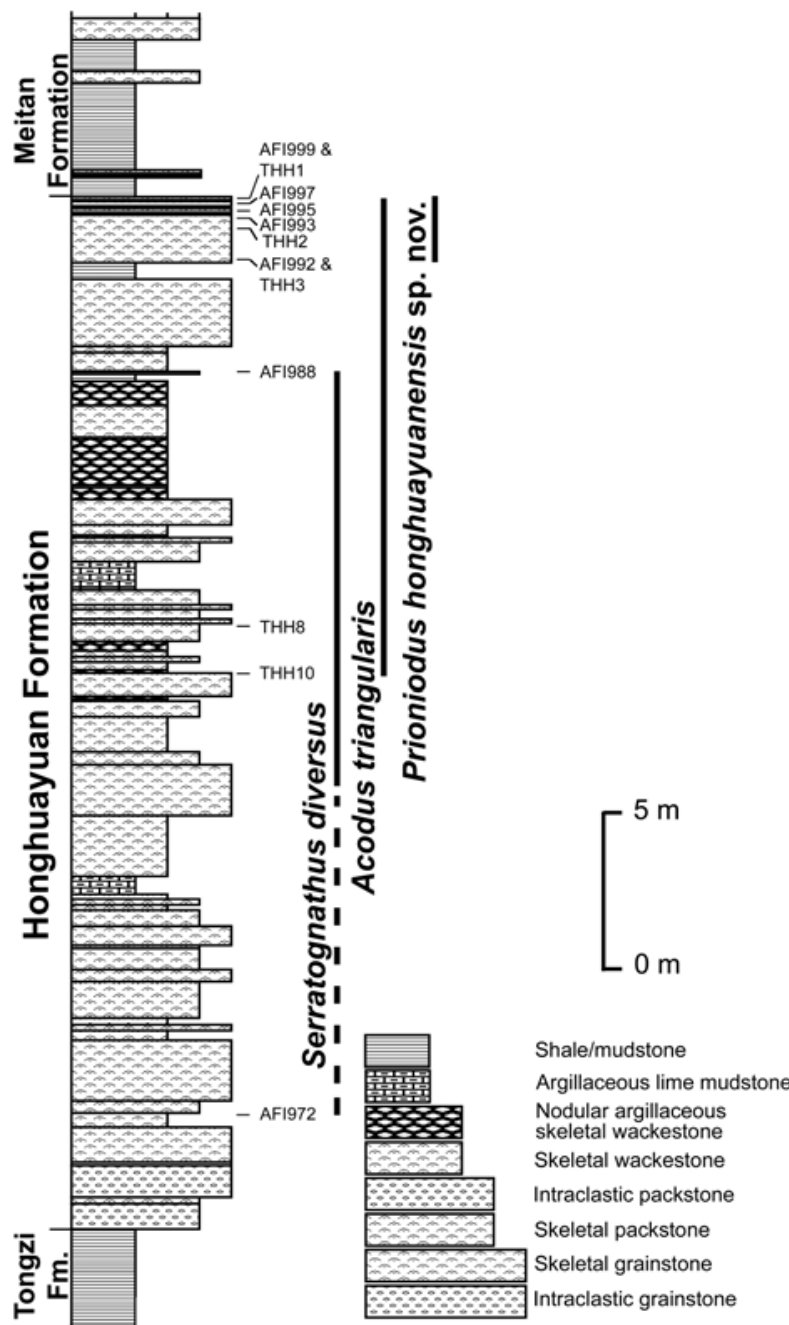

Fig. 2. Stratigraphic section through the Honghuayuan Formation at Honghuayuan, Tongzi, Guizhou Province showing the sampling positions and the stratigraphic ranges of Serratognathus diversus and the two species studied.

\section{Age and correlation of the Honghuayuan faunas}

The most characteristic feature of the conodont faunas from the Honghuayuan Formation is the abundance of Serratognathus diversus in the middle part of the formation (Fig. 2 ). This distinctive conodont species is apparently restricted in distribution to South China, the Tarim Basin (Zhao et al., 2000), and probably Australia (R.S. Nicoll, pers. comm.) and other biogeographically related tectonic units (Zhen et al. in Webby et al., 2000; Zhen \& Percival, 2003). An (1981, 1987) proposed the $S$. diversus Zone (divided into lower and upper subzones) based on the wide distribution of this species in South China, and correlated the lower subzone to the $P$. proteus Zone and the upper subzone to the $P$. elegans Zone of Baltoscandian successions. The $S$. diversus Zone was also approximately correlated with the $T$. approximatus graptolite Zone, evidenced by the occurrence of the $T$. approximatus fauna in deeper water clastic graptolitic facies laterally equivalent to the carbonate facies of the Honghuayuan Formation (X. Chen et al., 1995).

An $(1981,1987)$ also recognized the communis Zone ranging from the top of the Honghuayuan Formation to the basal part of the overlying Dawan Formation in South China, and correlated it with the communis Zone of North American Mid-continent successions. Although the age determination for the Honghuayuan Formation established by An (1981, 1987 ) is still current, the present study has demonstrated that the so-called "Baltoniodus communis" from South China of previous authors represents a new species of Prioniodus, $P$. honghuayuanensis named herein. It is neither conspecific nor congeneric with Oepikodus communis (Ethington \& Clark, 1964), an index zonal species of North American Mid-continent successions. Prioniodus honghuayuanensis in fact exhibits close relationships with a younger unnamed species of Prioniodus from the basal Whiterockian succession of the Ibex area, Utah. The morphological changes (documented herein) from adenticulate Acodus species to denticulate Prioniodus indicate the likely origin of Prioniodontid clade. Prioniodus honghuayuanensis may have evolved from an adenticulate species revised herein as Acodus triangularis (Ding in Wang, 1993), which first occurs in the middle of the Honghuayuan Formation (THH10, Fig. 2) and is also associated with P. honghuayuanensis at the top of the Formation. Morphologically Acodus triangularis resembles A. longibasis McTavish, 1973 from the Emanuel Formation of Western Australia, which also represents the primitive adenticulate prioniodontid species, but is probably of slightly younger age.

\section{Material and methods}

Twenty conodont samples (with prefix THH) were collected in 2000 from the Honghuayuan Formation in a $32 \mathrm{~m}$ thick limestone succession exposed on the hill slope to the southeast of Honghuayuan village (Fig. 1), about $10 \mathrm{~km}$ south of the Tongzi County. Acodus triangularis occurs in four samples (out of fifteen which yielded conodonts), whereas Prioniodus honghuayuanensis n.sp. was recovered from two samples at the top of the Formation (Table 1). All samples were completely dissolved in $10 \%$ acetic acid, with residues separated and concentrated using sodium polytungstate. Subsequently, 38 large samples (with prefix AFI) were recollected from the Honghuayuan Formation on this section (location coordinates: $28^{\circ} 04.27^{\prime} \mathrm{N} 106^{\circ}$ $50.91 ' \mathrm{E})$ to the southeast of the village. Both species were recovered from five samples at the top of the Honghuayuan Formation (Table 1).

In the Ganxi Section, measured along the road from Ganxi village to Shichangao, southwest of Yanhe County Town (Fig. 1, location coordinates: $28^{\circ} 22.72^{\prime} \mathrm{N} 108^{\circ}$ 25.70 'E), the Honghuayuan Formation consists of $71.8 \mathrm{~m}$ of thick-bedded limestones. Out of 27 productive samples collected from this section (with prefix YTH), only one from the top of the Honghuayuan Formation yielded Acodus triangularis and Prioniodus honghuayuanensis (Table 1).

All photographic illustrations shown in Figs 3-9 are SEM photomicrographs captured digitally (numbers with the prefix IY are the file names of the digital images). Figured specimens bear the prefix AMF and are deposited in the collections of the Palaeontology Section at the Australian Museum in Sydney. Authorship of the new species is attributable solely to Zhen. Conodont terminology and notation employed in this contribution are conventional as defined in the Treatise Part W (Clark et al., 1981), except for the M elements (makellate), whose orientation, morphology and terminology was introduced by Nicoll (1990, 1992). 
Table 1. Distribution of Acodus triangularis and Prioniodus honghuayuanensis n.sp., in ten samples of the Honghuayuan Formation at the Honghuayuan Section of Tongzi, and in one sample from the top of the Honghuayuan Formation at the Ganxi Section of Yanhe, Guizhou Province, South China.

\begin{tabular}{|c|c|c|c|c|c|c|c|c|c|c|c|c|c|c|c|c|c|}
\hline \multirow[b]{2}{*}{ Samples } & \multicolumn{9}{|c|}{ Acodus triangularis } & \multicolumn{8}{|c|}{ Prioniodus honghuayuanensis } \\
\hline & $\mathrm{Pa}$ & $\mathrm{Pb}$ & M & $\mathrm{Sa}$ & $\mathrm{Sb}$ & $\mathrm{Sc}$ & $\mathrm{Sd}$ & Total & $\mathrm{Pa}$ & $\mathrm{Pb}$ & ?Pc & M & $\mathrm{Sa}$ & $\mathrm{Sb}$ & $\mathrm{Sc}$ & $\mathrm{Sd}$ & Total \\
\hline AFI999 & 2 & - & 1 & - & - & - & - & 3 & 2 & 1 & 1 & 2 & 2 & 4 & 3 & 4 & 19 \\
\hline AFI997 & 13 & 5 & 6 & 5 & 4 & 2 & 7 & 42 & 9 & 4 & - & 7 & 13 & 12 & 11 & 16 & 72 \\
\hline AFI995 & 6 & - & - & 2 & 1 & 1 & 3 & 13 & 1 & 1 & - & 1 & 2 & 2 & 6 & 9 & 22 \\
\hline AFI993 & 26 & 26 & 18 & 7 & 2 & 3 & 11 & 93 & 34 & 11 & - & 38 & 26 & 53 & 27 & 103 & 292 \\
\hline AFI992 & 1 & 1 & 2 & 6 & 7 & 9 & 2 & 28 & 3 & - & - & 2 & - & 4 & - & 2 & 11 \\
\hline THH1 & - & - & - & - & - & - & - & - & - & - & - & - & - & - & 1 & - & 1 \\
\hline THH2 & - & - & 4 & 1 & - & - & - & 5 & - & - & - & - & - & - & - & - & - \\
\hline ТHH3 & 5 & 4 & 2 & 3 & 2 & 2 & 4 & 22 & - & - & - & 1 & 1 & - & - & 1 & 3 \\
\hline THH8 & 1 & 1 & - & - & - & - & 1 & 3 & - & - & - & - & - & - & - & - & - \\
\hline ТHH10 & 4 & - & $1 ?$ & 2 & 1 & 2 & 1 & 11 & - & - & - & - & - & - & - & - & - \\
\hline YTH1 & 1 & - & - & - & - & $1 ?$ & - & 2 & 3 & 1 & - & - & 1 & 5 & 2 & 3 & 15 \\
\hline Total & 59 & 37 & 34 & 26 & 17 & 20 & 29 & 222 & 52 & 18 & 1 & 51 & 45 & 80 & 50 & 138 & 435 \\
\hline
\end{tabular}

\section{Systematic palaeontology \\ Class Conodonta Pander, 1856 \\ Acodus Pander, 1856}

Type species. Acodus erectus Pander, 1856.

Remarks. The generic definition of Acodus and other related genera like Tripodus Bradshaw, 1969 and Tropodus Kennedy, 1980 has been a subject of disagreement among conodont workers (e.g., Lindström in Ziegler, 1977; Sweet, 1988, Kennedy, 1980; Albanesi in Albanesi et al., 1998; Johnston \& Barnes, 2000; X.H. Chen et al., 2003). It seems likely that there are more than one genus involved in these species embraced under a rather broad definition of Acodus given by Zhen et al. (2004). However, a serious revision of this species group, which will certainly need a monographic treatment, is far beyond the scope of the present project, and the level of our current understanding of these species does not yet support such a major revision. Acodus, defined as a multielement genus by Lindström (in Ziegler, 1977), is deeply entrenched in the Ordovician conodont literature. It was widely distributed in the Early and Middle Ordovician, and played a crucial part in the origin and early evolution of several major pectiniform clades like prioniodontids and balognothids (Stouge \& Bagnoli, 1999). We retain Acodus as a valid genus, although Pander's original specimens of the genotype, A. erectus, are irretrievably lost.

The type species of Tripodus, T. laevis Bradshaw, was originally defined as a form species on the basis of three specimens which show sharp anterior and posterior margins, a sharp blade-like costa on the outer lateral face situated more towards anterior margin, and a broad carina on the inner lateral face (Bradshaw, 1969). Based on material from the Ibex area of Utah, Ethington \& Clark (1982) revised the type species of Tripodus as consisting of a quinquimembrate apparatus. This is interpreted herein as including geniculate M (oistodiform element, see Ethington \& Clark, 1982, fig. 33A,B), alate triform Sa (trichonodelliform element, their fig. 33C), asymmetrical tetra-costate $\mathrm{Sb}$ (distacodiform element, their fig. 33F,G), asymmetrical laterally compressed $\mathrm{Sc}$ (drepanodiform element, their fig. $33 \mathrm{H}$ ), and asymmetrical multi-costate $\mathrm{Sd}$ (paltodiform element, their fig. 33D,E) elements. Apparently the type material of T. laevis would fall into the definition of the $\mathrm{Sb}$ element of the multi-element concept of the species, and the types of Scolopodus alatus Bradshaw, 1969, which Ethington \& Clark (1982) regarded as part of the T. laevis apparatus, include both Sa (Bradshaw, 1969, pl. 132, fig. 4, paratype) and Sd (Bradshaw, 1969, pl. 132, figs 1-3, holotype) elements. Ethington \& Clark (1982) also regarded Triangulodus van Wamel, 1974 as a junior synonym of their revised Tripodus. This raised the question as to whether Tripodus is likely a senior synonym of Triangulodus or a junior synonym of Acodus.

Based on material from western Newfoundland, Stouge (1984) regarded Tripodus as a junior synonym of Acodus, and suggested that Acodus combsi Bradshaw, 1969, T. laevis Bradshaw, and $S$. alatus Bradshaw represented different elements of one species apparatus which he called A. combsi. By assigning the prioniodiform $\mathrm{P}$ element represented by the form species A. combsi to the species apparatus, Stouge (1984) expanded the definition of T. laevis given by Ethington \& Clark (1982), although at the time he was unaware of their work. Further differentiation of the prioniodiform $\mathrm{Pa}$ and $\mathrm{Pb}$ elements has completed the species apparatus as septimembrate (Albanesi in Albanesi et al., 1998). Acodiform specimens assignable to the form species, A. combsi Bradshaw, 1969 were also reported from the Ibex area of Utah under the name "Scandodus" robustus Serpagli, 1974 (Ethington \& Clark, 1982, pl. 10, fig. 25). This species definition for T. laevis has been more or less accepted by many Ordovician conodont workers (Sweet, 1988, Stouge \& Bagnoli, 1988; Albanesi in Albanesi et al., 1998; Bergström \& Albanesi, 2001; Pyle et al., 2003), although others (Johnston \& Barnes, 2000; X.H. Chen et al., 2003) retained the original concept of oistodiform $\mathrm{M}$ and costate S elements only as defined by Ethington \& Clark (1982).

By taking A. combsi as the name bearer of the species, Stouge's work (1984) raised two questions: firstly, should T. laevis or A. combsi be the name bearer of the revised multi-element species, and secondly, to which genus should this species be assigned? In a recent documentation, Bergström \& Albanesi (2001) reviewed the validity of the species name Tripodus laevis, and concluded that based on the most recent edition of ICZN rules, T. laevis is the valid name and A. combsi is a junior synonym of T. laevis. As for 
the second question, some conodont workers follow Sweet (1988) in maintaining Tripodus as a valid genus and assigning Acodus as a nomina dubia, whereas others (e.g., Stouge \& Bagnoli, 1988; Johnston \& Barnes, 2000) utilize both Acodus and Tripodus by consigning species to the respective genus on historical reasons or on the details of the P and S elements. Based on the definitions of Acodus given by Lindström (in Ziegler, 1977) and of Triangulodus given by van Wamel (1974), both bear costate S and geniculate M elements, but Acodus has prioniodiform (acodiform) $\mathrm{P}$ elements instead of scandodiform P elements without costa on lateral faces as in Triangulodus. However, as discussed above, the form species of T. laevis may represent the $\mathrm{Sb}$ element of the multi-element species apparatus adopted herein. If Stouge's (1984) revision of $T$. laevis is accepted, Tripodus is likely a junior synonym of Acodus. Ethington (pers. comm., 2004) suggested that the $\mathrm{S}$ elements of Tripodus were much more ornate in their surface morphologies than typical Acodus as demonstrated by A. deltatus Lindström, 1955 and A. triangularis Ding described herein, and the $\mathrm{P}$ elements of T. laevis (A. combsi s.f. of Bradshaw) were deeply albid with very shallow basal cavities and without prominent carinae on the cusps. Until the type species of Tripodus can be revised in detail the taxonomic relationship of these two genera remains uncertain.

In the type sections of the Marathon Basin of Texas, all three form species (T. laevis, A. combsi and S. alatus) were established based only on a few specimens, and T. laevis and $A$. combsi were not found in association (Bradshaw, 1969). Furthermore, co-occurrence of Histiodella sinuosa (Graves \& Ellison) and Periodon aculeatus Hadding, 1913 in the Fort Peña fauna also suggests a younger age (Middle Ordovician, Yapeenian equivalent). Considering that the FAD (first-appearance datum) of $T$. laevis is a potential candidate for defining the base of the Middle Ordovician, detailed revision of this species at the type locality is urgently needed.

\section{Acodus triangularis (Ding in Wang, 1993)}

\section{Figs 3-5}

?Triangulodus cf. alatus Dzik.-An et al.: 1985: pl. 8, figs 1, 4, 8. ?Tripodus alatus (Dzik).-An, 1987: p. 193, pl. 16, figs 3-6. Oistodus triangularis Ding in Wang 1993: p. 185, pl. 19, figs 1, 2.

Material. 222 specimens from ten samples (Table 1).

Diagnosis. A species of Acodus consisting of a septimembrate apparatus including pastinate $\mathrm{Pa}$ and $\mathrm{Pb}$, makellate $\mathrm{M}$, triform alate $\mathrm{Sa}$, triform asymmetrical $\mathrm{Sb}$, modified cordylodiform Sc, and tetra-costate Sd elements; elements mostly albid and small in size, all bearing short adenticulate processes; $\mathrm{P}$ elements with a triangular base bearing a large, open basal cavity; S elements bearing a longer posterior process typically with a thin, blade-like crest along the upper edge.

Description. The pastinate $\mathrm{Pa}$ element has a reclined to suberect cusp and a large, triangular base (Fig. 3A-O). The cusp is triangular in cross section (Fig. 3F) with a sharp costa along the anterior and posterior margins, a mid-costa on the convex outer lateral face, and a smooth, more or less flattened inner lateral face. Three costae extend basally to merge with the upper margin of the anterior, posterior and outer lateral processes respectively (Figs 3A,G,K,I,M, 4 O). Fine striations are best developed in the area posterior to the outer lateral costa on the outer lateral face (Fig. 3L). All three processes have a blade-like upper edge (Fig. 3E,G) and an expanded base with posterior and anterior processes extending in the same plane (Fig. $3 \mathrm{H}$ ) or with anterior process slightly turned inner laterally (Fig. 3M-O). The outer lateral process extends basally and outer laterally in a direction nearly normal to the anteroposterior plane in upper or basal view (Fig. 3B,F), and is triangular in outline in anterior view (Fig. 3C,I) or posterior view (Fig. 3E). Posterior process extends posteriorly and typically longer than the other two (Fig. $3 \mathrm{G}, \mathrm{K}$ ). The anterior process is anticusp-like, triangular in outline in the lateral view (Fig. 3D,I$\mathrm{K})$. Basal cavity is pyramidal, large and moderately deep, with more or less straight basal margin or with both sides of the outer lateral process slightly restricted inward (Fig. 3B,H).

The $\mathrm{Pb}$ element is similar to the $\mathrm{Pa}$ element, but with a slightly proclined cusp (Fig. 4C,F,G,J,M), a shorter and less basally extended anterior process (Fig. 4A,B,G), a shorter and anterolaterally located outer lateral process (Fig. 4A,E,F,N), and a more open basal cavity (Fig. 4D,H). The side between the anterior process and the outer lateral process is less inwardly restricted, and the basal margins on both sides of the outer lateral process are less restricted inward in upper or basal view (Fig. 4B,D,E).

The $\mathrm{M}$ element is geniculate, anteroposteriorly compressed, with a low and well-developed outer lateral process and a short, anticusp-like inner lateral process, which is triangular in outline in anterior (Fig. 4K) or posterior view (Figs 3P, 4L). The anterior face is broadly convex and smooth, while the posterior face bears a broad carina and a weakly developed basal buttress. The basal margin is gently arched (Figs $3 \mathrm{P}, 4 \mathrm{~K}, \mathrm{~L}$ ).

The Sa element is triform and symmetrical with a robust cusp, a short adenticulate posterior process, and a bladelike adenticulate lateral process on the anterolateral corner of each side (Figs 4P-U, 5A). The cusp is isosceles triangular in cross section with a broad anterior face (Fig. 5A), a sharp costa along the posterior margin, and a sharp costa on each lateral side (Figs 4R,T, 5A). The three costae extend basally to form short, blade-like posterior and lateral processes (Fig. 4R,Q). Basal cavity is triangular in outline with moderate depth (Fig. 4R,U). Some specimens show a few small, rudimentary denticles along the thin upper edge of the posterior process (Fig. 4S).

The $\mathrm{Sb}$ element resembles the $\mathrm{Sa}$ element in being tricostate, but is distinguished by being markedly asymmetrical (Fig. 5B-J). The cusp is proclined, scalene triangular in cross section with a sharp costa along the anterior and posterior margins and a costa on the outer lateral face. The inner lateral face is concave and smooth or bearing a broad carina, with anterior margin prominently curved inwards (Fig. 5B,C,G). The outer lateral face is divided into a broadly convex area defined by the anterior costa and the outer lateral costa, and a gently concave area between the outer lateral costa and the posterior costa (Fig. 5D,F,H,I). The base is triangular in outline when posterior process is shorter (Fig. 5J), but in more advanced forms, it is strongly laterally compressed (Fig. 5E) as a long, adenticulate blade with a straight basal margin and a straight or weakly arched upper margin. The anterior process is anticusp-like, triangular in outline in the lateral view (Fig. 5I). The outer 


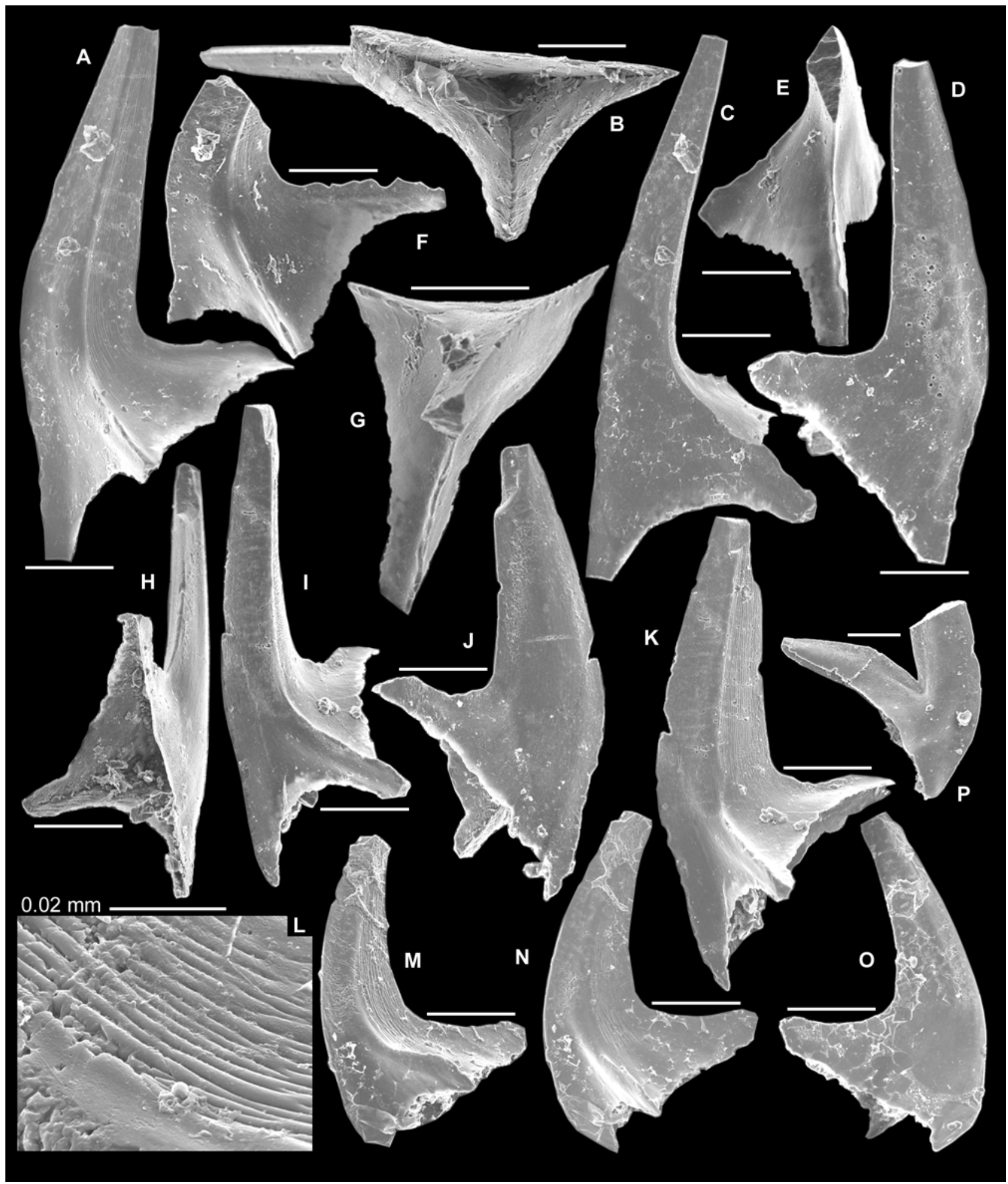

Fig. 3. Acodus triangularis (Ding in Wang, 1993): (A-D) Pa element, AMF126732, AFI993, (A) outer lateral view (IY52005), (B) basal view (IY64002), (C) antero-outer lateral view (IY52007), (D) inner lateral view (IY64001); $(E-G)$ Pa element, AMF126733, AFI993, $(E)$ upper-posterior view (IY52003), $(F)$ outer lateral view (IY52004), $(G)$ upper view (IY52001); $(H-K)$ Pa element, AMF126734, AFI993, $(H)$ basal view (IY52009), $(I)$ antero-outer lateral view (IY64005), $(J)$ inner lateral view (IY52008), $(K)$ outer lateral view (IY64003); $(L-O)$ Pa element, AMF126735, THH8, $(L)$ outer lateral view showing the fine striae in the area posterior to the outer lateral costa (IY64027), $(M)$ antero-outer lateral view (IY64026), $(N)$ outer lateral view (IY64025), $(O)$ inner lateral view (IY59016). ( $P$ ) M element, AMF126736, AFI992, posterior view (IY65034). Scale bars $100 \mu \mathrm{m}$ unless otherwise indicated.

[Fig.4 caption continued] ... (K,L) M element, AMF126740, AFI993, $(K)$ anterior view (IY64009), $(L)$ posterior view (IY52017). $(M, N)$ Pb element, AMF126741, THH3, $(M)$ outer lateral view (IY66032), $(N)$ antero-outer lateral view (IY66034). ( $O$ ) Pa element, AMF126742, THH10, outer lateral view (IY66037). $(P-R)$ Sa element, AMF126743, AFI993, $(P, Q)$ posterolateral views (IY66013, IY66014), $(R)$ basal-posterior view (IY66012). ( $S-U$ ) Sa element, AMF126744, AFI997, $(S)$ lateral view (IY66010), (T) posterior view (IY66009), $(U)$ basal view (IY66011). Scale bars $100 \mu \mathrm{m}$. 


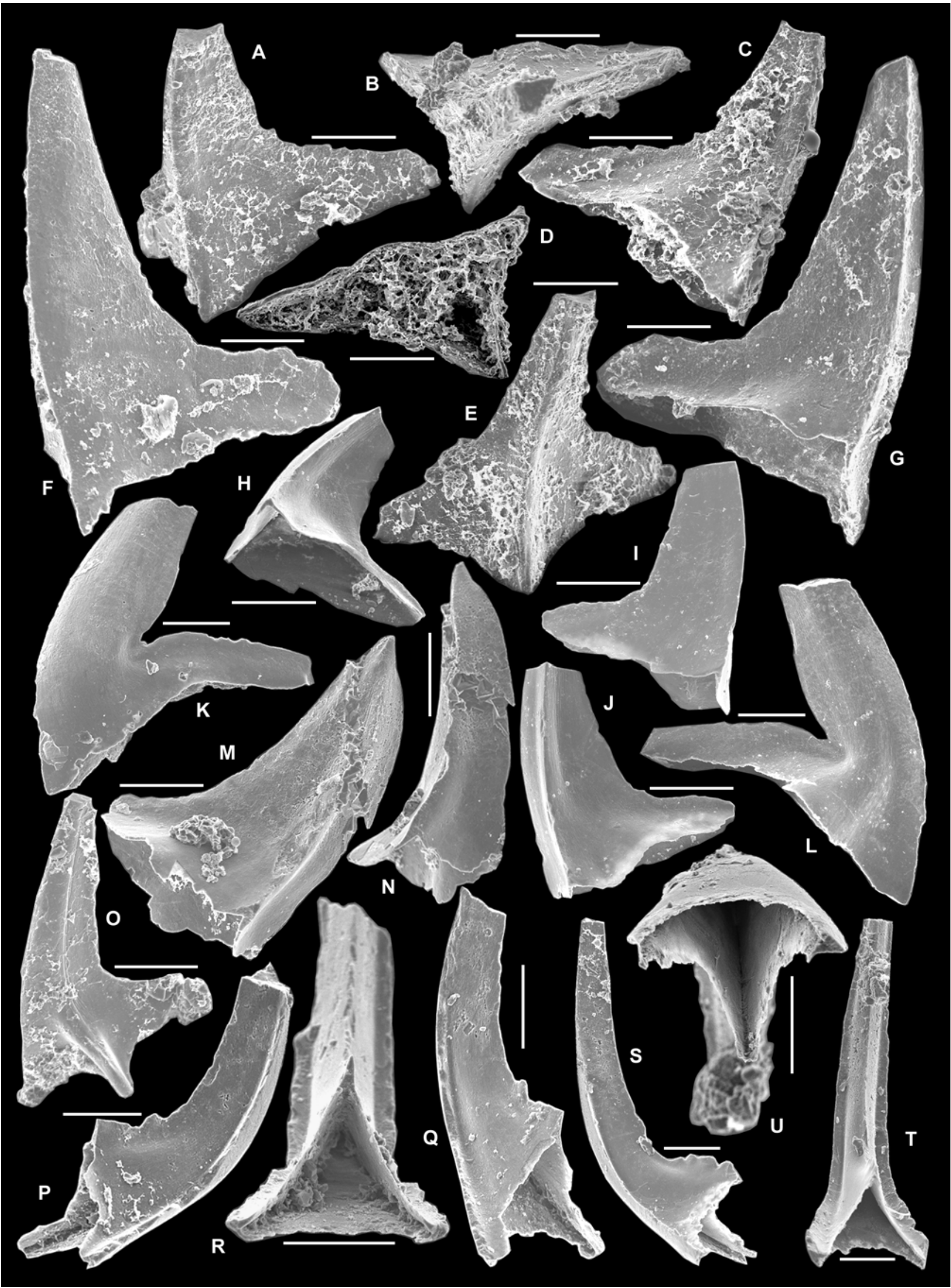

Fig. 4. Acodus triangularis (Ding in Wang, 1993): (A-E) Pb element, AMF126737, AFI992, (A) outer lateral view (IY53026), (B) upper view (IY53025), $(C)$ inner lateral view (IY65016), $(D)$ basal view (IY65017), $(E)$ antero-outer lateral view (IY53027); $(F, G)$ Pb element, AMF126738, AFI997, $(F)$ outer lateral view (IY64010), $(G)$ inner lateral view (IY52050); $(H-J)$ Pb element, AMF126739, AFI993, $(H)$ basal-inner lateral view (IY52011), (I) outer lateral view (IY64006), (J) inner lateral view (IY52010)... [continued p. 308] 


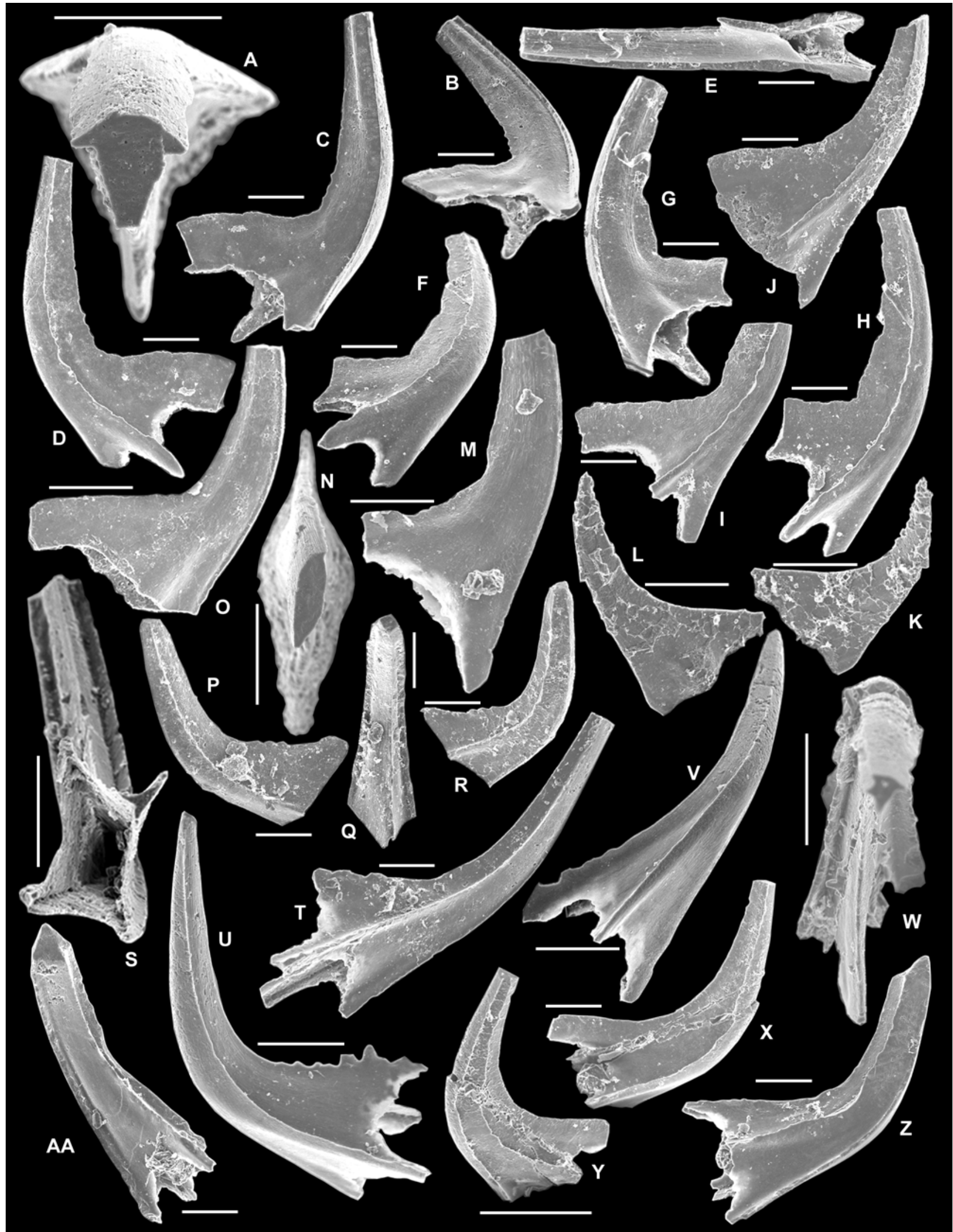

Fig. 5. Acodus triangularis (Ding in Wang, 1993): (A) Sa element, AMF126745, AFI992, upper view (IY66022). (B-D) Sb element, AMF126746, AFI992, (B) basal-inner lateral view (IY65013), $(C)$ inner lateral view (IY65012), $(D)$ outer lateral view (IY53036); $(E-H)$ Sb element, AMF126747, AFI992, $(E)$ posterior view (IY53037), $(F)$ antero-outer lateral view (IY65015), $(G)$ basal-inner lateral view (IY53038), $(H)$ outer lateral view (IY65014); (I) Sb element, AMF126748, AFI992, outer lateral view (IY65032); $(J)$ Sb element, AMF126749, AFI992, outer lateral view (IY66029). (K,L) Sc element, AMF126750, THH10, $(K)$ outer lateral view (IY66040), $(L)$ inner lateral view (IY66041); $(M)$ Sc element AMF126751, AFI992, inner lateral view (IY66027); $(N)$ Sc element, AMF126752, THH3, upper view (IY66031); (O) Sc element, AMF126753, AFI992, inner lateral view (IY66026). ... [continued p. 311] 
lateral process is also anticusp-like extending basally and outer-laterally with blade-like upper margin curved posteriorly. Basal cavity is moderately deep and triangular in outline and extends as narrow grooves underneath the posterior and anterior processes (Fig. 5B).

The Sc element is asymmetrical, strongly compressed laterally with a robust, proclined to suberect cusp, a posterior process varying from short (Fig. 5K,L) to relatively long (Fig. 5 O), and a short, anticusp-like anterior process (Fig. $5 \mathrm{~K}-\mathrm{O}$ ). The cusp is convex lens-like in cross section, slightly bent inward with a sharp costa along its anterior and posterior margins, and with smooth outer and inner lateral faces, or with a weakly developed broad carina on the inner lateral face (Fig. $5 \mathrm{O}$ ). The inner lateral face is less convex with anterior margin gently curved inward. Basal cavity is convex lens-like in outline with gently arched basal margin in lateral view (Fig. 5M).

The Sd element is tetra-costate and asymmetrical, with a sharp costa along the anterior and posterior margins, and a sharp costa on each lateral side (Fig. 5P-AA). The outer lateral side is more convex with a broad convex area between the anterior process and the outer lateral process, and a less convex to concave area defined by the outer lateral process and the posterior process (Fig. 5P,U). The inner lateral side is less convex to concave with an inner laterally curved anterior margin (Fig. 5R,T,Y). Costae extend basally to merge with the upper margin of four corresponding short, blade-like processes. Small rudimentary denticles may occur along the upper edge of the posterior process of some specimens (Fig. 5P). However, the broken upper edge in some specimens superficially exhibits a denticulate appearance (Fig. 5U).

Remarks. Oistodus triangularis was originally proposed as a form species with the type material from the Honghuayuan Formation of Anhui Province (Ding in Wang, 1993). The two figured specimens are both pastinate with a large, triangular base and a robust cusp which bears a sharp costa along its anterior and posterior margins, and a third costa on the outer lateral face (Ding in Wang 1993, p. 185). The holotype has a reclined cusp and less downwardly extending anterior process (Wang, 1993, pl. 19, fig. 1), whereas the other figured specimen (Wang, 1993, pl. 19, fig. 2), with a suberect cusp and a longer and more downwardly extending anterior process, is identical with the Pa element described herein from Guizhou.

Specimens previously referred to Triangulodus alatus Dzik, 1976 from the lower Dawan Formation of South China (An et al., 1985; An, 1987) possibly represent the S elements of Acodus triangularis. The type material of T. alatus, consisting of large-sized hyaline elements, occurs in late Darriwilian erratic boulders of NW Poland. The holotype (Dzik, 1976, p. 433, fig. 20k) is a scandodiform P element with an adenticulate posterior process and a short adenticulate anticusp-like anterior process. Dzik (1983, 1994) re-assigned this Baltic species to Eoneoprioniodus
Mound, 1965, which is likely a senior synonym of Triangulodus van Wamel, 1974 (see Clark et al., 1981). Triangulodus alatus was also reported from the upper Darriwilian (serra Zone) of the Tarim Basin (Zhao et al., 2000), and from the upper Darriwilian (serra Zone) of Oklahoma (Bauer, 1987).

Specimens referred to Acodus deltatus Lindström, 1955 from the Emanuel Formation of Western Australia (McTavish, 1973) are reassigned herein to A. longibasis which differs from A. deltatus mainly in having a more extended posterior process. This species from the Canning Basin shows some resemblance to A. triangularis from South China, in particular the $\mathrm{Pa}$ and $\mathrm{S}$ elements. Based mainly on the length of posterior process of the $S$ elements in the Emanuel Formation, McTavish (1973) split this species into several subspecies of $A$. deltatus including $A$. deltatus longibasis McTavish with long posterior process, A. deltatus deltatus with a shortest posterior process, and A. deltatus tortus McTavish with an inwardly twisted cusp of the $\mathrm{S}$ elements. Similar variations are also observed in the species from South China with the posterior process of the $\mathrm{S}$ elements varying from short (Fig. 5J,L,K) to relatively long (Fig. 5B-H,M,O).

\section{Prioniodus Pander, 1856}

\section{Type species. Prioniodus elegans Pander, 1856.}

Remarks. The type species of Oepikodus Lindström, 1955, O. smithensis Lindström, 1955, was originally proposed as a form species based on the oepikodiform elements (Lindström, 1955, pl. 6, figs 1-3). Subsequently, Lindström (1971) considered Oepikodus as a junior synonym of Prioniodus, 1856, and its type species, O. smithensis, along with Oistodus longiramis Lindström, 1955 to be parts of the revised multi-element species Prioniodus evae Lindström, which was also originally proposed as a form species based on the prioniodiform elements (Lindström, 1955, pl. 6, figs 4-10). Hence Lindström (1971) defined $P$. evae as consisting of a trimembrate apparatus including prioniodiform, oepikodiform and oistodiform elements. However, Bergström \& Cooper (1973, pp. 323-324) pointed out that "the apparatus of $P$. evae differs from that of $P$. elegans", the type species of Prioniodus, and "no element clearly homologous to the hibbardelliform element" existed in the latter. They further considered Oepikodus to be a subgenus of Prioniodus. This suggestion was formalized by Serpagli (1974). However, van Wamel (1974) and Lindström (in Ziegler, 1975) restored Oepikodus as a separate multi-element genus consisting of a trimembrate apparatus. Bergström (in Clark et al., 1981) and Stouge \& Bagnoli (1999) categorized Oepikodus and Prioniodus as belonging to different families.

Serpagli (1974) and Lindström (in Ziegler, 1975) redesignated the form species $P$. evae Lindström, 1955 as the type species of Oepikodus, since the originally

[Fig. 5 caption continued] ... (P-R) Sd element, AMF126754, AFI997, $(P)$ outer lateral view (IY53002), $(Q)$ posterior view (IY53001), $(R)$ inner lateral view (IY53003); $(S)$ Sd element, AMF126755, AFI997, basal-posterior view (IY66006); (T) Sd element, AMF126756, AFI997, inner lateral view (IY66001); (U,V) Sd element, AMF126757, AFI993, $(U)$ outer lateral view (IY66017), $(V)$ anterior view (IY66016); (W-Y) Sd element, AMF126758, THH3, $(W)$ upper view (IY58017), $(X)$ outer lateral view (IY58019), $(Y)$ inner lateral view (IY58018); $(Z, A A)$ Sd element, AMF126759, AFI993, $(Z)$ inner lateral view (IY66018), $(A A)$ posterior view (IY66020). Scale bars $100 \mu \mathrm{m}$. 
designated type species $O$. smithensis became a synonym of Prioniodus evae (see Lindström in Ziegler, 1975, p. 237). As correctly pointed out by van Wamel (1974, p. 74), the form species $O$. smithensis is not a junior synonym of the form species $P$. evae, and the form species $O$. smithensis must therefore remain as the type species of Oepikodus. Although $O$. smithensis has page priority among the three form species erected by Lindström in the same publication for three different genera, they (O. smithensis Lindström, 1955, P. evae Lindström, 1955, and Oistodus longiramis Lindström, 1955) form the apparatus of a multi-element species, which was named as $P$. evae by Lindström (1971). With Lindström (1971) as the first reviser (see Article 24.2.2, ICZN of 1999 edition), O. evae (Lindström, 1955) emend. Lindström (1971) is recognized as a valid and proper name of the species with this multi-element apparatus.

Following the definition of Oepikodus as trimembrate (van Wamel, 1974) and then quadrimembrate (Bergström in Clark et al., 1981), Stouge \& Bagnoli (1988) suggested that Oepikodus consisted of a seximembrate apparatus that could be distinguished from Prioniodus by lack of the Sa element. Albanesi (in Albanesi et al., 1998) concurred with this concept.

Oepikodus, as most recently revised by Nicoll \& Ethington (2004), was defined as consisting of a septimembrate apparatus including pastinate $\mathrm{Pa}$ and $\mathrm{Pb}$, makellate $\mathrm{M}$ and quadriramate $\mathrm{S}$ (Sa, Sb, Sc and $\mathrm{Sd}$ ) elements. Prioniodus consists of a similar septimembrate apparatus that includes a triform alate Sa element, rather than a quadriform alate Sa element as in Oepikodus. Therefore, occurrence of the triform alate $\mathrm{Sa}$ element in the new species from the Honghuayuan Formation confirms its generic assignment to Prioniodus.

\section{Prioniodus honghuayuanensis n.sp.}

Figs 6-8

Baltoniodus communis (Ethington \& Clark).-An, 1981: pl. 4, figs 20-23, 25, 27-29, ?24.

Baltoniodus communis (Ethington \& Clark).-An \& Ding, 1985: p. 8,9 , pl. 1, figs $1-5,8, ? 9$.

Baltoniodus? communis (Ethington \& Clark).-An, 1987: p. 125, 126, pl. 19, figs $1-11$.

Baltoniodus communis (Ethington \& Clark).-Ding et al. in Wang, 1993: p. 161, pl. 23, figs 1-12.

Etymology. After Honghuayuan Village, where the type section of the Honghuayuan Formation is exposed on the hill slope located to the southeast of the village.

Material. 435 specimens, including holotype (AMF126760, from sample AFI993) and 19 paratypes (AMF126761AMF126779), from eight samples (Table 1).

Diagnosis. Species of Prioniodus consisting of a septimembrate apparatus, including pastinate $\mathrm{Pa}$ and $\mathrm{Pb}$ elements with denticulate posterior and outer lateral process and adenticulate (or with rudimentary denticles) anterior process which curves distally outer laterally; makellate M element with low but long inner lateral and outer lateral processes; alate triform Sa, triform asymmetrical (modified quadriramate) $\mathrm{Sb}$, bipennate (modified quadriramate) $\mathrm{Sc}$, and quadriramate Sd elements; all S elements with a proclined cusp, a long denticulate posterior process, and adenticulate (or rudimentarily denticulated) lateral and anterior processes.

Description. All elements are small, mostly albid, thin and fragile; the long denticulate posterior process of the $\mathrm{P}$ and $\mathrm{S}$ elements is broken in most specimens. Pastinate $\mathrm{P}$ elements bear a robust, laterally compressed cusp, with a sharp costa along its anterior and posterior margins, and with a prominent costa on the outer lateral face (Fig. 6). Surface of the cusp is ornamented with fine striation, which are best developed posterior to the outer lateral process on the outer lateral face (Fig. 6P). The posterior process is laterally compressed as a long blade with closely spaced, basally confluent, and more or less equal-sized denticles along its upper margin. The anticusp-like anterior process extends downward with its anterior margin strongly curved outwards and occasionally with confluent and small rudimentary denticles along its edge (Fig. 6F). The outer lateral costa extends downward to merge with the upper margin of the outer lateral process, which is long and bearing small, closely spaced denticles (Fig. 6B,M,N). The outer lateral process that extends downward laterally outward with an angle slightly $>90^{\circ}(\mathrm{Pb}$, Fig. 6O) or nearly normal $(\mathrm{Pa}$, Fig. $6 \mathrm{D}, \mathrm{G})$ to the posterior process is often broken in the present collection. Basal cavity is triangular in shape extending underneath the three processes as narrow grooves (Fig. 6E,F,Q,O). The Pa element has a suberect cusp with anterior process curved laterally outward and with the outer lateral process extending nearly normal to the posterior process in the upper view (Fig. 6D,G). The Pb element resembles the $\mathrm{Pa}$, but with a reclined cusp and an innerlaterally bent posterior process (Fig. 6K-S).

The $\mathrm{M}$ element has a robust and strongly outer laterally reclined cusp, and adenticulate, low and long outer lateral and inner lateral processes (Fig. 7A-D). The cusp is sightly curved posteriorly and anteroposteriorly compressed, with a weak costa on the broad anterior face, and a broad carina on the posterior face. The outer lateral process has gently arched upper and basal margins, while the inner lateral process has nearly straight upper and basal margins. Basal cavity is relatively narrow, without prominent basal buttress (Fig. 7B,C).

The Sa element is triform and symmetrical with a proclined cusp, a long denticulate posterior process, and an anticusplike lateral process on each side (Fig. 7E-S). The cusp is triangular in cross section with a broad anterior face (Fig. 7M, $\mathrm{O})$, a sharp blade-like costa along the posterior margin, and a sharp costa along the anterolateral corner of each side (Fig. 7J, $\mathrm{S})$. The posterior process is long, straight and strongly compressed laterally bearing small, closely spaced denticles (Fig. 7P-R). The blade-like costa on each side is gently curved posteriorly and extends basally to merge with the upper margin of the lateral process, which often bears rudimentary denticles (Fig. 7J,R). The basal cavity is an isosceles triangle in outline with moderate depth (Fig. 7E,J).

[Fig.6 caption continued] ... AMF126762, $(K)$ inner lateral view (IY63005), $(L)$ outer lateral view (IY63006), $(M)$ upper view (IY63007), $(N)$ anterior view (IY63004), $(O)$ basal view (IY50035), $(P)$ close up of outer lateral view, showing the fine striae in the area posterior to the outer lateral costa (IY50036); $(Q-S)$ Pb element, paratype, AMF126763, $(Q)$ basal view (IY50027), $(R)$ inner lateral view (IY63011), $(S)$ outer lateral view (IY50028). All from sample AFI993; scale bars $100 \mu$ m unless otherwise indicated. 


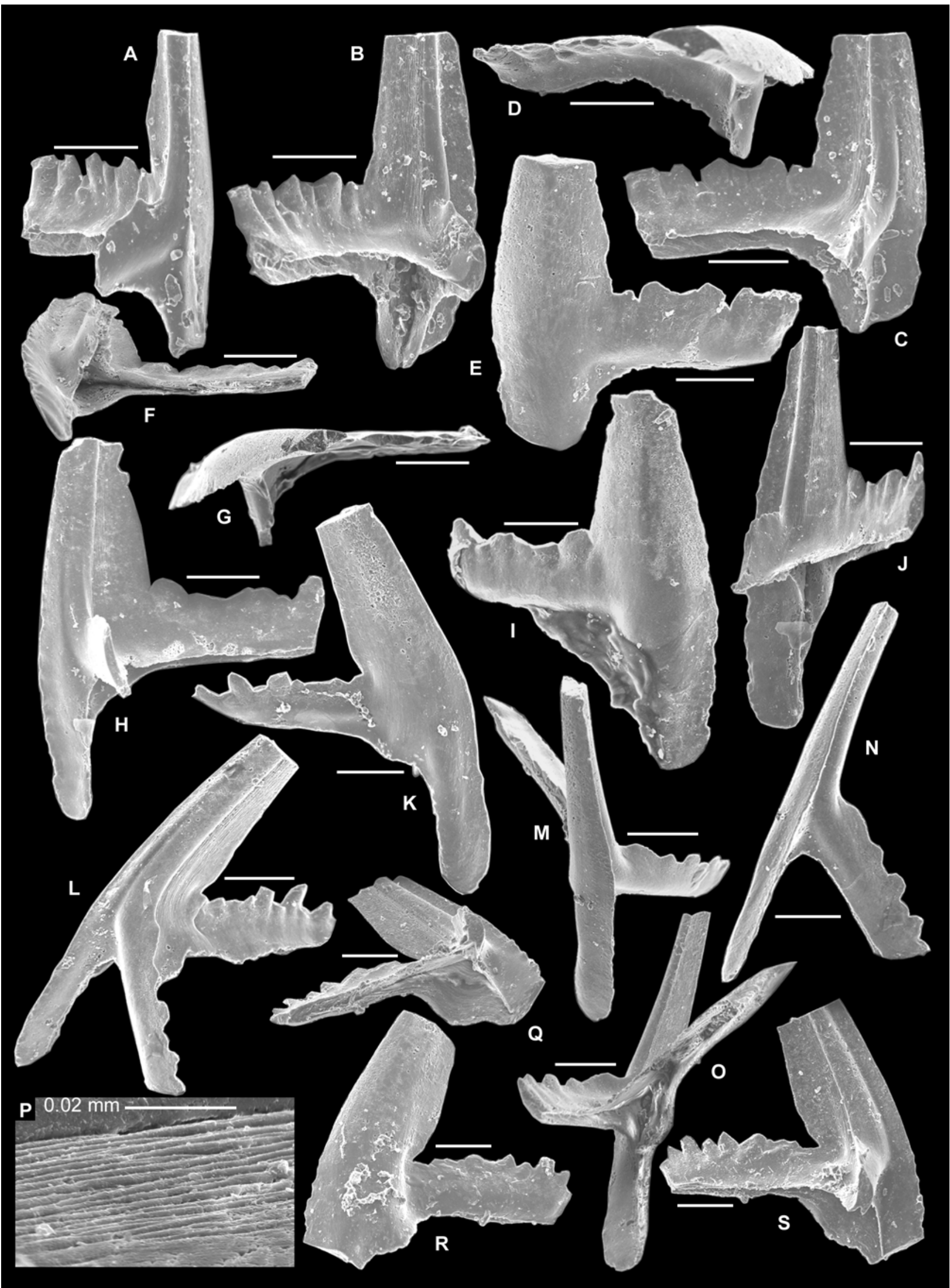

Fig. 6. Prioniodus honghuayuanensis n.sp.: (A-E) Pa element, paratype, AMF126761, $(A)$ antero-outer lateral view (IY50030), (B) basal-outer lateral view (IY50032), $(C)$ outer lateral view (IY50033), $(D)$ upper view (IY63010), $(E)$ inner lateral view (IY63009); $(F-J)$ Pa element, holotype, AMF126760, $(F)$ basal view (IY50039), $(G)$ upper view (IY63003), $(H)$ outer lateral view (IY50038), $(I)$ inner lateral view (IY63001), $(J)$ postero-outer lateral view (IY50040). $(K-P) \mathrm{Pb}$ element, paratype, $\ldots$ [continued $p$. 312] 


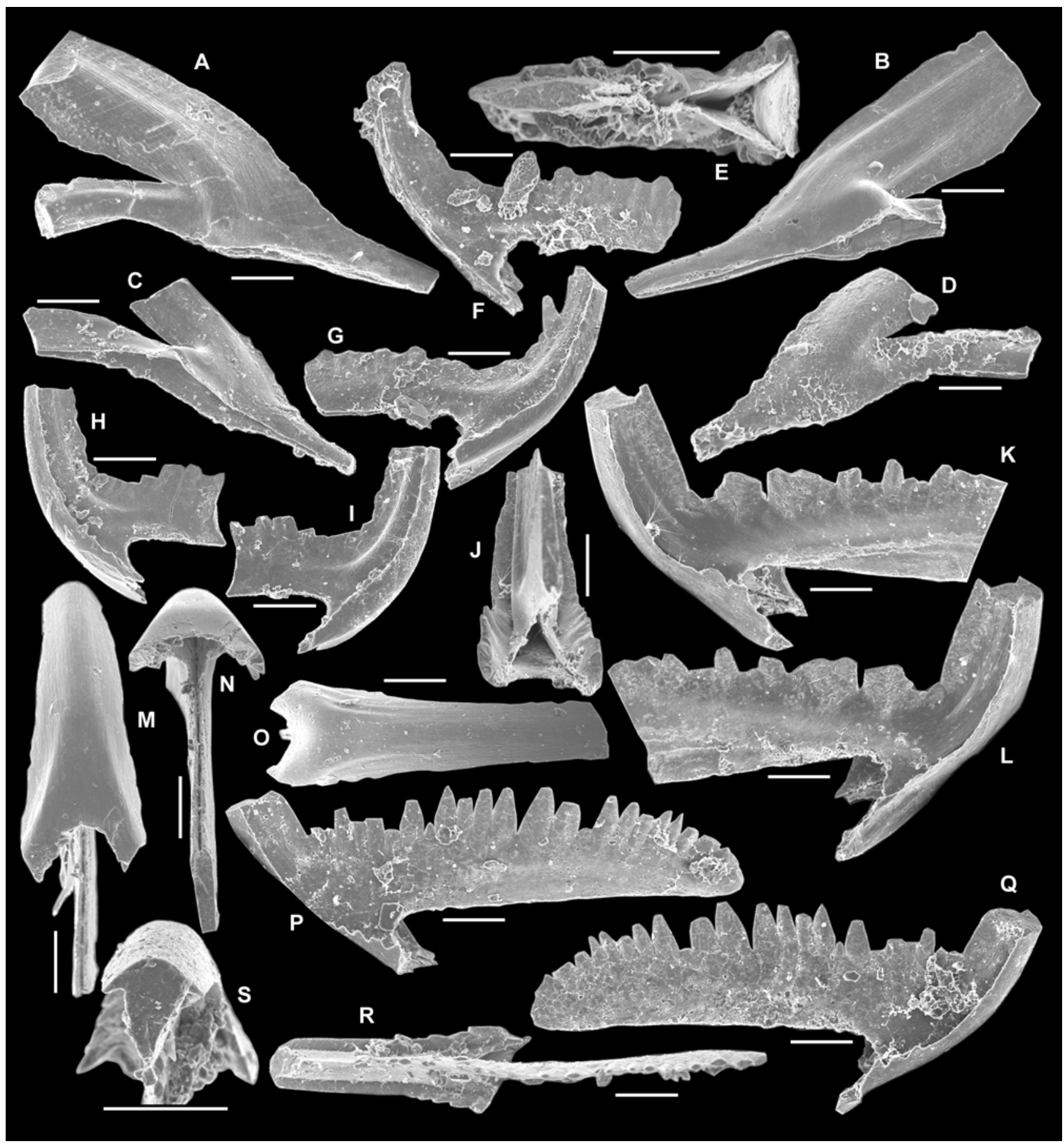

Fig. 7. Prioniodus honghuayuanensis n.sp.: $(A, B)$ M element, paratype, AMF126764, AFI993, $(A)$ anterior view (IY51011), $(B)$ posterior view (IY63016); (C,D) M element, paratype, AMF126765, AFI993, (C) basal-posterior view (IY51015), $(D)$ anterior view (IY63018). (E-G) Sa element, paratype, AMF126766, AFI993, $(E)$ basal view (IY51003), $(F, G)$ lateral views (IY51002, IY63012); $(H, I)$ Sa element, paratype, AMF126767, AFI993, lateral views (IY63013, IY51005); ( $J-N)$ Sa element, paratype, AMF126768, AFI993, $(J)$ basal-posterior view (IY51009); $(K, L)$ lateral views (IY51010, IY51008), $(M)$ anterior view (IY63014); $(N)$ basal view (IY63015); $(O)$ Sa element paratype, AMF126769, AFI993, anterior view (IY51006); $(P-S)$ Sa element, paratype, AMF126770, AFI997, $(P, Q)$ lateral views (IY51046, IY51048), $(R)$ upper view (IY51045), $(S)$ upper view showing the cross section of the cusp (IY63026). Scale bars $100 \mu \mathrm{m}$.

[Fig.8 caption continued] ... AMF126774, AFI993, $(I)$ inner lateral view (IY63021), $(J)$ outer lateral view (IY51026), $(K)$ basal view (IY51025); $(L-P)$ Sc element, paratype, AMF126775, AFI997, $(L)$ basal view (IY51050), $(M)$ inner lateral view (IY51049), $(N)$ outer lateral view (IY63028), $(O)$ upper view (IY51051), $(P)$ close up of the upper view showing the cross section of the cusp (IY51052); $(Q)$ Sc element, paratype, AMF126776, AFI993, outer lateral view (IY51022). $(R-T)$ Sd element, paratype, AMF126777, AFI993, $(R)$ outer lateral view (IY63025), $(S)$ inner lateral view (IY51037), $(T)$ posterior view (IY51036); $(U-X)$ Sd element, paratype, AMF126778, AFI993, $(U)$ inner lateral view (IY63023), $(V)$ outer lateral view (IY51033), $(W)$ posterior view (IY51035), $(X)$ postero-outer lateral view (IY51034); $(Y-A A)$ Sd element, paratype, AMF126779, AFI993, $(Y)$ postero-inner lateral view (IY51032), $(Z)$ outer lateral view (IY63022), $(A A)$ inner lateral view (IY51031). Scale bars $100 \mu \mathrm{m}$ unless otherwise indicated. 


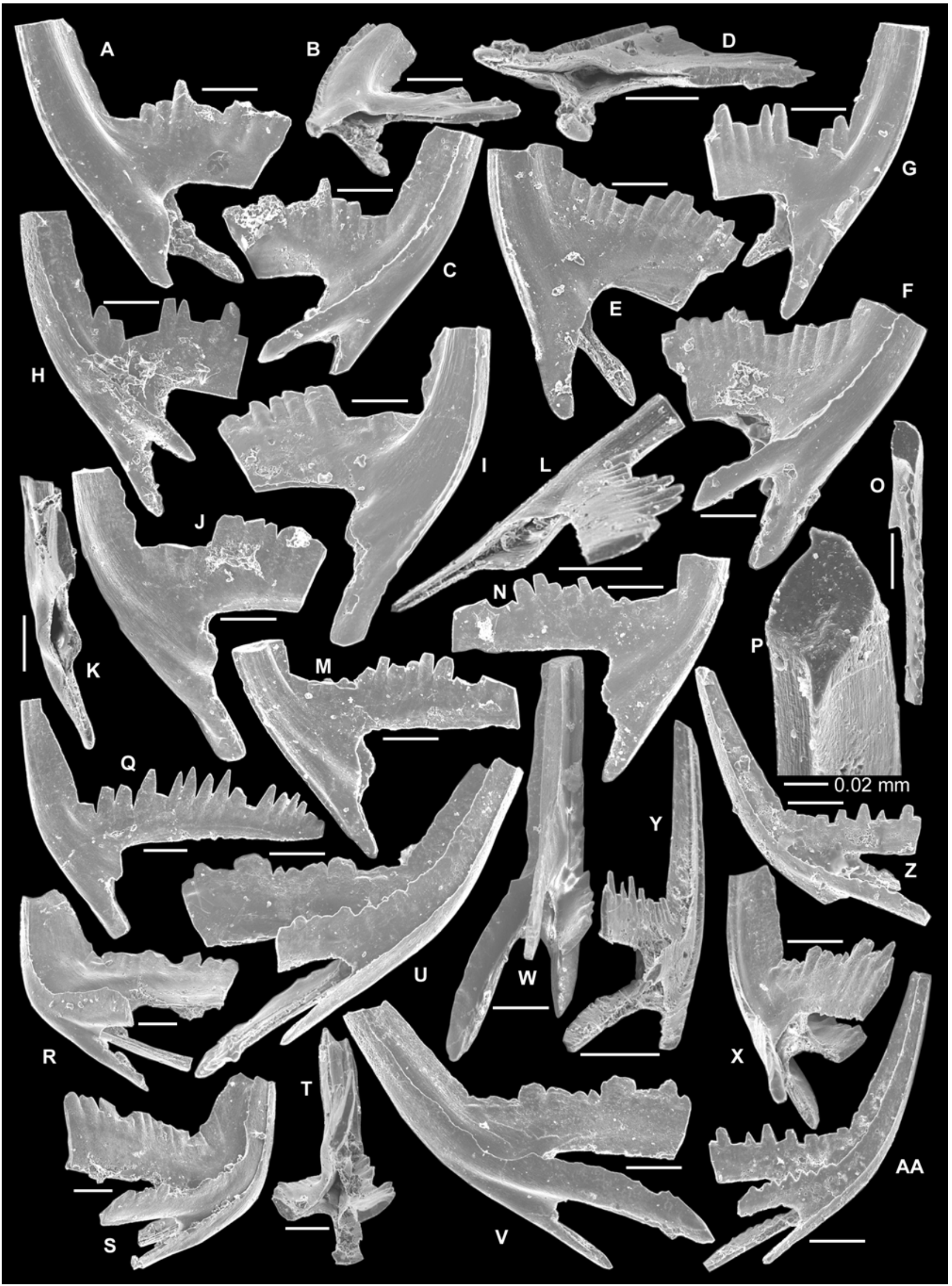

Fig. 8. Prioniodus honghuayuanensis n.sp.: (A-C) Sb element, paratype, AMF126771, AFI993, (A) inner lateral view (IY51013), (B) basal-inner lateral view (IY51014), $(C)$ outer lateral view (IY63017); $(D-F)$ Sb element, paratype, AMF126772, AFI993, $(D)$ basal view (IY51020), $(E)$ inner lateral view (IY51021), $(F)$ outer lateral view (IY63020); $(G, H)$ Sb element, paratype, AMF126773, AFI993, $(G)$ inner lateral view (IY63019), $(H)$ outer lateral view (IY51017). (I-K) Sc element, paratype, ... [continued p. 314$]$ 
The Sb element is strongly asymmetrical with a proclined and laterally compressed cusp, which bears a sharp costa along the anterior and posterior margins, and the third costa on the outer lateral face (Fig. 8A-H). The anterior costa is inner laterally curved and extends basally to merge with the upper margin of the anticusp-like downwardly extending adenticulate anterior process (Fig. 8A,E,G). The long posterior process is laterally compressed as a high blade bearing small, closely spaced denticles of similar sizes along its upper margin. The costa on the outer lateral face extends downward to merge with the upper margin of the downward extended, shorter, adenticulate outer lateral process. The inner lateral face is less convex, and bears a broad carina (Fig. 8A,B,E,G).

The Sc element is bipennate with a broad carina on each lateral face (more prominent on the inner lateral face), a short, adenticulate anterior process, and a long, laterally compressed, denticulate posterior process (Fig. 8I-Q). The cusp is proclined (Fig. 8Q), and laterally compressed with a sharp blade-like costa along its posterior and anterior margins (Fig. 8 O,P), which extends basally to merge respectively into the upper margin of the anterior process and the posterior process (Fig. 8I,M). The anterior process is anticusp-like, and curved laterally inward (Fig. 8I,M). The posterior process bears small, closely spaced denticles of more or less similar sizes (Fig. 8Q). The basal cavity is biconvex in outline, and extends as a narrow groove underneath the anterior and posterior processes (Fig. 8K,L).

The Sd element is quadriramate and asymmetrical, with an anterior process, a posterior process, and a lateral process on each side (Fig. 8R-AA). The cusp is proclined with a sharp blade-like costa along the anterior and posterior margins and on each lateral side (Fig. 8T,W,Y,AA). Anterior costa is inner laterally curved (Fig. 8S,U,Y), and extends basally to merge into the upper margin of the anticusp-like anterior process which is adenticulate or has small, fused rudimentary denticles along its distal edge (Fig. 8Y). As in the other S elements, the posterior process is long, laterally compressed, and blade-like bearing small, closely spaced denticles of similar sizes. The area defined by the anterior costa and the outer lateral costa is more broadly convex (Fig. 8R,V). The lateral costa on each side extends basally to merge respectively with the upper margin of the short inner and outer lateral processes. Both lateral processes extend downward and often bear small rudimentary denticles along their distal edges (Fig. 8S-U,W,X,AA).

Remarks. Although P elements of the new species show some resemblance to those of Oepikodus communis (Ethington \& Clark, 1964), they differ in having denticulate outer lateral processes, and an anterior process which bears rudimentary denticles along its distal edge. The anterior process of $P$. honghuayuanensis extends strongly downward as an anticusp, and curves strongly outer laterally (Fig. 6F,J,Q). The Pb element of $O$. pincallyensis Zhen in Zhen at al., 2003 has denticulate anterior, outer lateral and posterior processes, but the anterior process of the $\mathrm{Pa}$ element is adenticulate. However, the P elements of $O$. pincallyensis are distinctively curved inner laterally (Zhen et al., 2003, fig. 19E,K) rather than outer laterally as in $P$. honghuayuanensis (Fig. 6D,M). Furthermore, the S elements of the new species can be easily distinguished from those of $O$. communis, $O$. pincallyensis and other species of Oepikodus. The Sa element is triform and alate with a wide anterior face (Fig. 7M,O) and the open basal cavity is an isosceles triangle in outline (Fig. 7E,J). The Sb element can be described as asymmetrical triform (or modified quadriramate of some authors) with a strongly developed costa on the outer lateral face, which extends basally as a short but prominent adenticulate outer lateral process. The quadriramate $\mathrm{Sd}$ element of $P$. honghuayuanensis differs from that of $O$. communis in having more strongly developed costae, in having more prominent lateral processes, and in tending to develop rudimentary denticles along the distal edge of the anterior and lateral processes (Fig. 8S-U,W-Y,AA).

Oepikodus communis was originally proposed as a form species based on pastinate elements (Ethington \& Clark, 1964). The type material shows a long denticulate posterior process with small, closely spaced denticles, and adenticulate anterior and outer lateral processes (Ethington \& Clark, 1964, pl. 114, figs 6, 14, text-fig. 2F). Subsequently, Ethington \& Clark (1982) revised O. communis in multielement taxonomy by accommodating another three form species which were reported in association with the type material of the form species Gothodus communis Ethington \& Clark, 1964 in the El Paso Formation of Texas. These include Oepikodus equidentatus Ethington \& Clark, 1964 with typical quadriramate ramiform elements (including symmetrical and asymmetrical), Subcordylodus sp. aff. S. delicatus (Branson \& Mehl) with modified quadriramate ramiform elements (bearing only a weakly developed broad carina on the lateral faces), and Oistodus longiramis Lindström, 1955 comprising a makellate element with a long and slender outer lateral process. Ethington \& Clark (1982) recognized the symmetry transition among the ramiform elements of four morphotypes, symmetrical quadriramate element, asymmetrical quadriramate element, modified quadriramate element with costa on one side, and modified quadriramate element without lateral costa. Therefore, they indicated a seximembrate apparatus for the species, although no formal notation was made. Repetski (1982) also suggested a seximembrate apparatus for $O$. communis, including prioniodiform, falodiform and four types of ramiform (belodiform, tetraprioniodiform, hibbardelliform, and cordylodiform) elements. Nicoll \& Ethington (2004) defined Oepikodus as consisting of a septimembrate apparatus of a geniculate makellate $\mathrm{M}$, four types of quadriramate or modified quadriramate $\mathrm{S}$, and two types of pastinate $\mathrm{P}$ elements.

We also interpret Oepikodus communis as consisting of a septimembrate apparatus. The pastinate $\mathrm{Pa}$ element is represented by the holotype (Ethington \& Clark, 1964, pl. 114, fig. 6) with a suberect cusp, and the pastinate $\mathrm{Pb}$ element by the other figured specimen of $G$. communis (Ethington \& Clark, 1964, pl. 114, fig. 14) with a reclined cusp. The Sa and Sd elements are represented by the form species O. equidentatus Ethington \& Clark (1964, pl. 113, figs $6,8,10,11,14)$. The Sa element is symmetrical or nearly symmetrical with a straight anterior margin, while the Sd element is markedly asymmetrical with a curved anterior margin (e. g. Ethington \& Clark, 1964, pl. 113, fig. 14). The Sc element of $O$. communis is represented by those described and illustrated by Ethington \& Clark (1964, p. 701, pl. 115, figs 1, 5, 7, 10) as Subcordylodus sp. aff. S. delicatus (Branson \& Mehl, 1933). The makellate M element of $O$. communis is represented by those described and illustrated by Ethington \& Clark (1964, p. 693, pl. 114, figs 2,7$)$ as Oistodus longiramis Lindström, 1955. The 


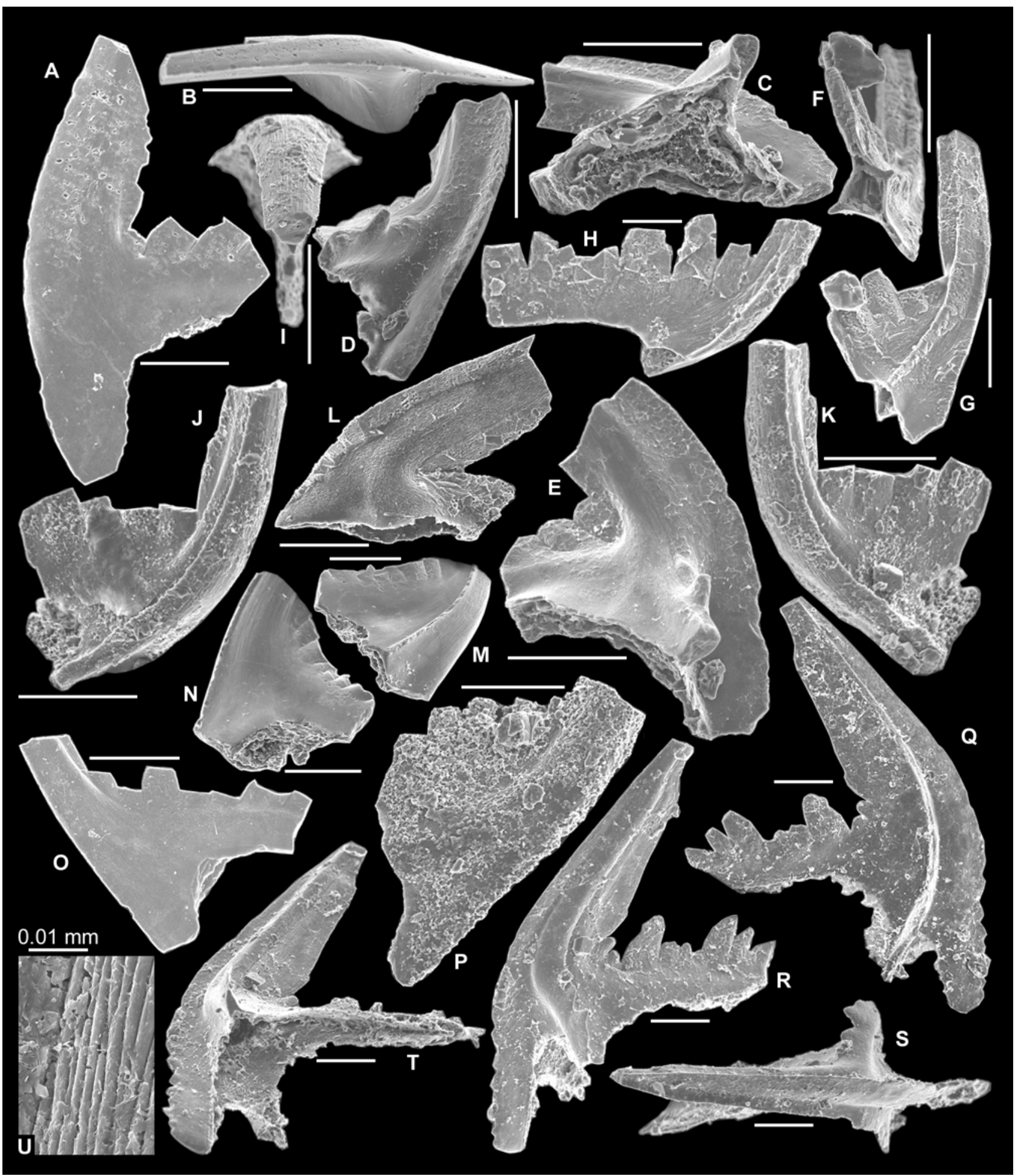

Fig. 9. A-P, Prioniodus sp.: (A,B) Pa element, AMF126781, 100 feet above base of Kanosh Fm., Utah, (A) inner lateral view (IY66053), $(B)$ upper view (IY66054). (C-E) Pb element, AMF126782, 83 feet above base of Kanosh Fm., Utah, $(C)$ basal view (IY66051), $(D)$ antero-outer lateral view (IY66052), $(E)$ outer lateral view (IY66050). ( $F, G)$ Sd element, AMF126783, 78J-23, 150 feet above base of Juab Fm., Utah, $(F)$ basal view (IY66061), $(G)$ inner lateral view (IY66062). (H) Sa element, AMF126784, 78J-23, 150 feet above base of Juab Fm., Utah, lateral view (IY66060); (I-K) Sa element, AMF126785, 78J-16, top ledge of Wah Wah Fm., Utah, $(I)$ anteroupper view (IY66042), $(J, K)$ lateral views (IY66045, IY66043). $(L)$ M element, AMF126786, 78J-16, top ledge of Wah Wah Fm., Utah, posterior view (IY66049). (M,N) Sb element, AMF126787, 100 feet above base of Kanosh Fm., Utah, $(M)$ outer lateral view (IY66065), $(N)$ inner lateral view (IY66066). $(O)$ Sc element, AMF126788, 57 feet above base of Kanosh Fm., Utah, inner lateral view (IY66063); $(P)$ Sc element, AMF126789, 78J-16, top ledge of Wah Wah Fm., Utah, outer lateral view (IY66047). $(Q-U)$ Prioniodus ?honghuayuanensis n.sp.: ?Pc element, AMF126780, AFI999, $(Q)$ inner lateral view (IY53012), $(R)$ outer lateral view (IY65010), $(S)$ upper view (IY53010), $(T)$ outer-basal view (IY65008), $(U)$ close up of outer lateral view showing fine striae in the area posterior to outer lateral costa (IY65009); Scale bars $100 \mu \mathrm{m}$ unless otherwise indicated. 
asymmetrical $\mathrm{Sb}$ element is a modified quadriramate element with a more prominent costa on the outer lateral face (Albanesi in Albanesi et al., 1998, pl. 6, fig. 22).

Oepikodus intermedius Serpagli, 1974, from the San Juan Formation of the Argentine Precordillera, is regarded herein as conspecific with $O$. communis; it was originally described as consisting of a trimembrate apparatus (prioniodiform, oistodiform and oepikodiform). In more recent revisions of the San Juan faunas, both Lehnert (1995) and Albanesi (in Albanesi et al., 1998) did not recognize symmetrical Sa elements in any of the three species $(O$. communis, $O$. intermedius and O. evae) they ascribed to Oepikodus.

Lindström (in Ziegler, 1975) considered the form species Gothodus microdentatus van Wamel, 1974 from the Glauconitic Limestone of Sweden as part of O. communis species apparatus. However, not only have the wellrecognized elements of $O$. communis apparatus not been recorded in association with this form species in Sweden, but also the triform, asymmetrical G. microdentatus shows rather different morphology in comparison with the ramiform elements of $O$. communis from North America. Based on the original description and illustrations (van Wamel, 1974), the form species G. microdentatus more likely represents the $\mathrm{Sb}$ element of a multi-element species of Prioniodus rather than of Oepikodus.

Oepikodus communis is widely distributed in North America (Ethington \& Clark, 1964, 1982; Repetski, 1982; Stouge, 1982; Stouge \& Bagnoli, 1988; Johnston \& Barnes, 2000), Argentine Precordillera (Serpagli, 1974; Lehnert, 1995; Albanesi in Albanesi et al., 1998), Australia (McTavish, 1973; Zhen et al., 2003), and Greenland (Smith, 1991). However, as the result of inclusion of a triform alate Sa element in this species apparatus by An and other Chinese authors (An, 1981, 1987; An et al., 1985; Ding et al. in Wang, 1993), the occurrence of O. communis in South China needs to be re-examined.

Specimens referable to the $\mathrm{Pa}, \mathrm{Pb}, \mathrm{Sa}, \mathrm{Sb}, \mathrm{Sc}$ and $\mathrm{Sd}$ elements of the present new species were first recorded from the top of the "Honghuayuan Formation" of Hexian, Anhui Province as Baltoniodus communis (An, 1981, 1987; An \& Ding, 1985). An (1987) noted the abundant occurrence (up to $80 \%$ in some samples) of this species at the top of the Honghuayuan Formation in Guizhou, Hunan, Hubei and Anhui provinces, and correlated this interval at the top of the Honghuayuan Formation with the communis Zone of North America and with the elegans Zone of Baltoscandia. Although he recognized the occurrence of triform alate element as part of this species apparatus, An $(1981,1987)$ included this material into his rather broad interpretation of O. communis (Ethington \& Clark, 1964). However, as the triform Sa element occurring in the material from South China had not been recognized at the type locality of $O$. communis in North America, An $(1981,1987)$ doubtfully assigned $O$. communis to Baltoniodus rather than Oepikodus.

Specimens previously referred to as aff. Oepikodus? minutus (McTavish, 1973) from the upper Wah Wah Formation, and the overlying Juab and Kanosh formations in the Ibex area of Utah (Ethington \& Clark, 1982) somewhat resemble $P$. honghuayuanensis. Prof. R. Ethington kindly provided sixty specimens of this Utah species from nine samples for comparative study. Stratigraphically the Ibex species (designated herein as Prioniodus sp.; Fig. 9A-P) occurs at a slightly younger level (basal Whiterockian, victoriae graptolite Zone) than the new species from South China. Similarities include the prioniodiform $\mathrm{Pb}$ element of Prioniodus sp. (Fig. 9C-E) that bears a denticulate outer lateral process with anterior margin curved outer laterally towards outer lateral process, and the ramiform $\mathrm{S}$ series that includes alate triform $\mathrm{Sa}$ (Fig. 9H-K), asymmetrical triform $\mathrm{Sb}$ (Fig. 9M,N), bipennate Sc (Fig. 9 O,P), and quadriramate Sd (Fig. 9F,G) elements. However, the associated $\mathrm{M}$ element of the Ibex species shows a much shorter inner lateral process, and the $\mathrm{Pa}$ element has an adenticulate and weakly developed outer lateral process and a more or less straight anterior process. Bagnoli \& Stouge (1997) referred this Ibex species to Gothodus Lindström, 1955. Based on the recent revision of Gothodus (Bagnoli \& Stouge, 1997, and Stouge \& Bagnoli, 1999), it has prioniodiform P elements comparable with those of Oepikodus and Prioniodus, but the S elements are more related to Phragmodus Branson \& Mehl, 1933. However, most other conodont authors regard it as a junior synonym of Prioniodus (e.g., Bergström in Clark et al., 1981) or Baltoniodus (Bagnoli et al., 1988).

The new species from the Honghuayuan Formation shows some resemblance to P. elegans documented from Sweden by van Wamel (1974, p. 87-89, pl. 6, figs 1-6) and by Löfgren (1978, pl. 9, figs 1-6), but Swedish material of P. elegans has the M element with a denticulate inner lateral process and the $\mathrm{P}$ and $\mathrm{S}$ elements with better developed denticles on the lateral and anterior processes. Prioniodus elegans described from the Leningrad region of Russia and Tulubäcken of Sweden by Bergström (1988, pl. 3, figs 3338 ), and from western Newfoundland by Stouge \& Bagnoli (1988, pl. 13, figs 1-9) and Johnston \& Barnes (2000, pl. 3, figs $1,5-7,11$, pl. 16, fig. 17) has an even stronger development of denticulation with $\mathrm{P}$ elements bearing a longer, fully denticulated anterior process, and with $\mathrm{S}$ elements displaying well-denticulated anterior and lateral processes. The multi-element species definition of P. elegans followed herein conforms to the concept of Bergström (1971, 1981 in Clark et al., 1981), van Wamel (1974), and Stouge \& Bagnoli (1988). Stouge \& Bagnoli (1988, p. 134) noted that this species displayed a large degree of morphological variation and might be polymorphic. Some of the material of P. elegans documented by Bergström (1988, pl. 3, figs 33-37) came from Popowka to the south of the Leningrad region, from where Pander's original type material (now lost) was collected. In comparison with those figured specimens of $P$. elegans, the $\mathrm{P}$ elements of $P$. honghuayuanensis display a more prominent cusp and smaller and less developed anterior and outer lateral processes (Fig. 6H,L), the $\mathrm{P}$ and $\mathrm{S}$ elements show less development of denticles on the anterior and lateral processes (Figs 6-8), and the $\mathrm{M}$ element lacks denticles on the inner lateral process (Fig. 7A-D). Also, the anterior process of the $\mathrm{P}$ elements in P. elegans is distinctively curved inner laterally (Bergström, 1988, pl. 3, fig. 33) rather than outer laterally (Fig. $6 \mathrm{D}, \mathrm{F}, \mathrm{G})$ as in $P$. honghuayuanensis. In South China, $P$. elegans has only been recorded from the Jinshan Formation (biostratigraphically coeval with the Honghuayuan Formation) in Zhejiang Province of southeast China (An, 1987). It was also recorded from sub-surface core samples of the Tarim Basin, northwest China (Zhao et al., 2000).

One specimen from the very top of the Honghuayuan Formation at the Honghuayuan Section (AFI999, Fig. 2) is 
similar to the $\mathrm{Pb}$ element of $P$. honghuayuanensis, but is stellate in outline with an additional sharp, blade-like costa on the inner side of the cusp, which extends basally into a short process with a few small rudimentary denticles. It is tentatively referred to herein as a Pc element of $P$. honghuayuanensis (Fig. 9Q-U).

ACKNOWLEDGMENTS. Fieldwork by YYZ in Guizhou in late 2000 was undertaken with the support of the Australian Academy of Sciences and the Academia Sinica (visiting grant). Professors Zhiyi Zhou and Jiayu Rong from Nanjing Institute of Geology and Palaeontology, Academia Sinica kindly provided financial assistance and made arrangement for the shipment of the conodont samples to Australia (NSFC projects 40272001, and Major Basic Research Projects of MST, China G2000077703). Further collecting in Tongzi was undertaken by JBL in the following years (2001 to 2002) with the support of the Special Funds for Major State Basic Research Project (G200077700) of P.R. China, and these samples were processed at the Palaeontology Laboratory of the Geology Department, Peking University. Y.Y. Zhen's study of the conodont fauna was partially funded by a Sydney Grammar School Science Fellowship. Prof. R. Ethington kindly provided material of a Prioniodus species from the Wah Wah, Juab and Kanosh formations of the Ibex area, Utah for comparative study. Gary Dargan (Geological Survey of New South Wales) assisted with acid leaching, residue separation and other laboratory work. Scanning electron microscope photographs were prepared in the Electron Microscope Unit of the Australian Museum. Reviews by $\mathrm{R}$, Ethington and G. Albanesi assisted clarification of our ideas. IGP publishes with permission of the Director, Geological Survey of NSW.

\section{References}

Albanesi, G.L., M.A. Hünicken \& C.R. Barnes, 1998. Bioestratigrafía, biofacies y taxonomia de conodontes de las secuencias ordovícicas del Cerro Porterillo, Precordillera central de San Juan, R. Argentina. Actas de la Academia Nacional de Ciencias 12: $1-249$.

An, T.X., 1981. Recent progress in Cambrian and Ordovician conodont biostratigraphy of China. Geological Society of America Special Paper 187: 209-226.

An, T.X., 1987. Early Paleozoic conodonts from South China. Beijing: Peking University Publishing House. (In Chinese with English abstract).

An, T.X., \& L.S. Ding, 1985. Ordovician conodont biostratigraphy in Hexian, Anhui Province. Geological Review 31: 1-12.

An, T.X., G.Q. Du \& Q.Q. Gao, 1985. Ordovician conodonts from Hubei. Beijing: Geological Publishing House. (In Chinese with English abstract).

Bagnoli, G., \& S. Stouge, 1997. Lower Ordovician (BilingenianKunda) conodont zonation and provinces based on sections from Horns Udde, north Öland, Sweden. Bollettino della Società Paleontologica Italiana 35: 109-163.

Bagnoli, G., S. Stouge \& M. Tongiorgi, 1988. Acritarchs and conodonts from the Cambro-Ordovician Furuhäll (Köpingsklint) Section (Öland, Sweden). Revista Italiana di Paleontologia e Stratigrafia 94(2): 163-248.

Bauer, J.A., 1987. Conodonts and conodont biostratigraphy of the McLish and Tulip Creek formations (Middle Ordovician) of south-central Oklahoma. Oklahoma Geological Survey, Bulletin 141: 1-55.

Bergström, S.M., 1988. On Pander's Ordovician conodonts: distribution and significance of the Prioniodus elegans fauna in Baltoscandia. Senckenbergiana lethaea 69: 217-251.
Bergström, S.M., \& G.L. Albanesi, 2001. Validity of the species name Tripodus laevis Bradshaw, 1969. Ordovician Stratigraphy Discussion Group internet site: http://seis.natsci.csulb.edu/ordstrat2/default.htm. http://seis.natsci.csulb.edu/ORDSTRATDOCS/Validity_of_name_T._laevis.htm

Bergström, S.M., \& R.A. Cooper, 1973. Didymograptus bifidus and the trans-Atlantic correlation of the Lower Ordovician. Lethaia 6: 313-340.

Bradshaw, L.E., 1969. Conodonts from the Fort Peña Formation (Middle Ordovician), Marathon Basin, Texas. Journal of Paleontology 43: 1137-1168.

Branson, E.R., \& M.G. Mehl, 1933. Conodont studies. University of Missouri Studies 8: 1-349.

Chang, M.S., \& S.F. Sheng, 1958. The Ordovician formations along the Szechuan-Kweichow Border. Acta Geologica Sinica 38: $326-342$.

Chen, X., J.Y. Rong, X.F. Wang, Z.H. Wang, Y.D. Zhang \& R.B. Zhan, 1995. Correlation of the Ordovician rocks of China: charts and explanatory notes. International Union of Geological Sciences, Publication 31: 1-104.

Chen, X.H., X.F. Wang, Z.H. Li \& C.S. Wang, 2003. Elaborate biostratigraphic subdivision and correlation of the basal Dawan Stage (Middle Ordovician) in Yangtze Platform, China. Acta Palaeontologica Sinica 42: 317-327.

Chen, X.Y., M.H. Peng \& C.S. Jin, 1995. Lower Ordovician conodonts from Tudi'ao, Yanhe County, Guizhou. Acta Micropalaeontologica Sinica 12: 323-332.

Clark, D.L., W.C. Sweet, S.M. Bergström, G. Klapper, R.L. Austin, F.H.T. Rhodes, K.J. Müller, W. Ziegler, M. Lindström, J.F. Miller \& A.G. Harris, 1981. Conodonta. In Treatise on Invertebrate Paleontology, part W, Miscellanea, supplement 2, ed. R.A. Robison. Boulder: Geological Society of America, and Lawrence: University of Kansas.

Dzik, J., 1976. Remarks on the evolution of Ordovician conodonts. Acta Palaeontologica Polonica 21: 395-455.

Dzik, J., 1983. Relationships between Ordovician Baltic and North American Midcontinent conodont faunas. Fossils and Strata 15: 59-85.

Dzik, J., 1994. Conodonts of the Mójcza Limestone. In Ordovician carbonate platform ecosystem of the Holy Cross Mountains, ed. J. Dzik, E. Olempska \& A. Pisera. Palaeontologica Polonica 53: 43-128.

Ethington, R.L., \& D.L. Clark, 1964. Conodonts from the El Paso Formation (Ordovician) of Texas and Arizona. Journal of Paleontology 38: 685-704.

Ethington, R.L., \& D.L. Clark, 1982. Lower and Middle Ordovician conodonts from the Ibex area, western Millard County, Utah. Brigham Young University, Geological Studies 28(2): $1-160$.

Gao, D.D., 1976. The Ordovician System of Guizhou. Huishui: Stratigraphy and Palaeontology Team, Geology Bureau of Guizhou. (In Chinese).

Johnston, D.I., \& C.R. Barnes, 2000. Early and Middle Ordovician (Arenig) conodonts from St. Pauls Inlet and Martin Point, Cow Head Group, western Newfoundland, Canada. 2. Systematic paleontology. Geologica et Palaeontologica 34: 11-87.

Kennedy, D.J., 1980. A restudy of conodonts described by Branson and Mehl, 1933, from the Jefferson City Formation, Lower Ordovician, Missouri. Geologica et Palaeontologica 14: 4576; Marburg.

Lehnert, O., 1995. Ordovizische Conodonten aus der Präkordillere Westargentiniens: Ihre Bedeutung für Stratigraphie und Paläogeographie. Erlanger Geologische Abhandlungen 125: 1-193.

Lindström, M., 1955. Conodonts from the lowermost Ordovician strata of south-central Sweden. Geologiska Föreningens $i$ Stockholm Förhandlingar 76: 517-604. 
Lindström, M., 1971. Lower Ordovician conodonts of Europe. In Symposium on conodont biostratigraphy, ed. W.C. Sweet \& S.M. Bergström. Geological Society of America, Memoir 127: 21-61.

Löfgren, A., 1978. Arenigian and Llanvirnian conodonts from Jämtland, northern Sweden. Fossils and Strata 13: 1-129.

McTavish, R.A., 1973. Prioniodontacean conodonts from the Emanuel Formation (Lower Ordovician) of Western Australia. Geologica et Palaeontologica 7: 27-58.

Nicoll, R.S., 1990. The genus Cordylodus and a latest Cambrianearliest Ordovician conodont biostratigraphy. BMR Journal of Australian Geology \& Geophysics 11: 529-558.

Nicoll, R.S., 1992. Analysis of conodont apparatus organisation and the genus Jumudontus (Conodonta), a coniform-pectiniform apparatus structure from the Early Ordovician. BMR Journal of Australian Geology \& Geophysics 13: 213-228.

Nicoll, R.S., \& R.L. Ethington, 2004. Lissoepikodus nudus gen. et sp. nov. and Oepikodus cleftus sp. nov., new septimembrate conodont taxa from the Early Ordovician of Australia and Nevada. Courier Forschungsinstitut Senckenberg 245: 427-461.

Pander, C.H., 1856. Monographie der fossilen Fische des Silurischen Systems der Russisch-Baltischen Gouvernements. St. Petersburg: Akademie der Wissenschaften.

Pyle, L.J, C.R. Barnes \& Z.L. Ji, 2003. Conodont fauna and biostratigraphy of the Outram, Skoki, and Owen Creek formations (Lower to Middle Ordovician), Wilcox Pass, Alberta, Canada. Journal of Paleontology 77(5): 958-976.

Repetski, J.E., 1982. Conodonts from E1 Paso Group (Lower Ordovician) of westernmost Texas and southern New Mexico. New Mexico Bureau of Mines \& Mineral Resources, Memoir 40: 1-121.

Serpagli, E., 1974. Lower Ordovician conodonts from Precordilleran Argentina (Province of San Juan). Bollettino della Società Paleontologica Italiana 13: 17-98.

Smith, M.P., 1991. Early Ordovician conodonts of East and North Greenland. Meddelelser om Grønland, Geoscience 26: 1-81.

Stouge, S., 1982. Preliminary conodont biostratigraphy and correlation of Lower to Middle Ordovician carbonates of the St. George Group, Great Northern Peninsula, Newfoundland. Newfoundland Department of Mines \& Energy Report 82-3: $1-59$.

Stouge, S., 1984. Conodonts of the Middle Ordovician Table Head Formation, western Newfoundland. Fossils and Strata 16: 1-145.

Stouge, S., \& G. Bagnoli, 1988. Early Ordovician conodonts from Cow Head Peninsula, western Newfoundland. Palaeontographica Italica 75: 89-179.

Stouge, S., \& G. Bagnoli, 1999. The suprageneric classification of some Ordovician prioniodontid conodonts. In Studies on Conodonts Proceedings of the Seventh European Conodont Symposium, Bologna-Modena, 1998, ed. E. Serpagli. Bollettino della Società Paleontologica Italiana 37: 145-158.

Sweet, W.C., 1988. The Conodonta: Morphology, Taxonomy, Paleoecology, and Evolutionary History of a Long-Extinct Animal Phylum. Oxford: Clarendon Press. van Wamel, W.A., 1974. Conodont biostratigraphy of the Upper Cambrian and Lower Ordovician of north-western Öland, south-eastern Sweden. Utrecht Micropalaeontological Bulletins 10: 1-125.

Wang, C.Y., ed., 1993. Conodonts of the Lower Yangtze Valleyan index to biostratigraphy and organic metamorphic maturity. Beijing: Science Press. (in Chinese with English summary).

Wang, X.F., X. Chen, X.H. Chen \& C.X. Zhu, eds, 1996. Lexicon of Stratigraphy of China: Ordovician. Beijing: Geological Publishing House. (In Chinese).

Webby, B.D., I.G. Percival, G. Edgecombe, F. Vandenberg, R. Cooper, J. Pickett, J. Pojeta Jr, G. Playford, T. WinchesterSeeto, Y.Y. Zhen, R.S. Nicoll, J.R.P. Ross, R. Schallreuter \& G. Young, 2000. Ordovician biogeography of Australasia. In Palaeobiogeography of Australasian faunas and floras, ed. A. Wright, J. Talent \& G. Young. Association of Australian Palaeontologists, Memoir 23: 63-126.

Zhang, W.T., H.K. Xu, X. Chen, J.Y. Chen, K.X. Yuan, Y.K. Lin \& J.G. Wang, 1964. Ordovician of the Northern Guizhou. In Palaeozoic Rocks of Northern Guizhou, ed. Nanjing Institute of Geology and Palaeontology, Academia Sinica, pp. 33-78. Nanjing: Nanjing Institute of Geology and Palaeontology. (In Chinese).

Zhao, Z.X., G.Z. Zhang \& J.N. Xiao, 2000. Paleozoic stratigraphy and conodonts in Xinjiang. Beijing: Petroleum Industry Press. (In Chinese with English abstract).

Zhen, Y.Y., \& I.G. Percival, 2003. Ordovician conodont biogeography-reconsidered. Lethaia 36: 357-369.

Zhen, Y.Y., I.G. Percival \& B.D. Webby, 2003. Early Ordovician conodonts from western New South Wales, Australia. Records of the Australian Museum 55(2): 169-220. www.amonline.net.au/pdf/publications/1383_complete.pdf

Zhen, Y.Y., I.G. Percival \& B.D. Webby, 2004. Early Ordovician (Bendigonian) conodonts from central New South Wales, Australia. Courier Forschungsinstitut Senckenberg 245: 39-73.

Zhu, Z.D., Y.W. Jiang \& B.L. Liu, 1995. Palaeoecology of late Tremadocian reef-bearing strata in western Hubei Province of China. In Ordovician Odyssey: Short papers for the Seventh International Symposium on the Ordovician System, ed. J.D. Cooper, M.L. Droser \& S.C. Finney. SEPM Pacific Section, Book 76, 427-428. Fullerton, California.

Ziegler, W., ed., 1975. Catalogue of conodonts. II: 1-403. Stuttgart: E. Schweizerbart'sche.

Ziegler, W., ed., 1977. Catalogue of conodonts. III: 1-574. Stuttgart: E. Schweizerbart'sche.

Manuscript received 6 September 2004, revised 8 December 2004 and accepted 21 December 2004.

Associate Editor: G.D. Edgecombe. 